\title{
Ocean warming and acidification modulate energy budget and gill ion regulatory mechanisms in Atlantic cod (Gadus morhua)
}

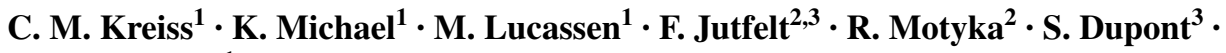 \\ H. -O. Pörtner ${ }^{1}$
}

Received: 1 December 2014 / Revised: 29 June 2015 / Accepted: 15 July 2015 / Published online: 29 July 2015

(C) The Author(s) 2015. This article is published with open access at Springerlink.com

\begin{abstract}
Ocean warming and acidification are threatening marine ecosystems. In marine animals, acidification is thought to enhance ion regulatory costs and thereby baseline energy demand, while elevated temperature also increases baseline metabolic rate. Here we investigated standard metabolic rates (SMR) and plasma parameters of Atlantic cod (Gadus morhua) after 3-4 weeks of exposure to ambient and future $\mathrm{PCO}_{2}$ levels $(550,1200$ and $2200 \mu \mathrm{atm})$ and at two temperatures $\left(10,18^{\circ} \mathrm{C}\right)$. In vivo branchial ion regulatory costs were studied in isolated, perfused gill preparations. Animals reared at $18{ }^{\circ} \mathrm{C}$ responded to increasing $\mathrm{CO}_{2}$ by elevating SMR, in contrast to specimens at $10{ }^{\circ} \mathrm{C}$. Isolated gills at $10{ }^{\circ} \mathrm{C}$ and elevated $\mathrm{PCO}_{2}$ $(\geq 1200 \mu \mathrm{atm})$ displayed increased soft tissue mass, in parallel to increased gill oxygen demand, indicating an increased fraction of gill in whole animal energy budget. Altered gill size was not found at $18{ }^{\circ} \mathrm{C}$, where a shift in the use of ion regulation mechanisms occurred towards enhanced $\mathrm{Na}^{+} / \mathrm{H}^{+}$-exchange and $\mathrm{HCO}_{3}{ }^{-}$transport at high $\mathrm{PCO}_{2}(2200 \mu \mathrm{atm})$, paralleled by higher $\mathrm{Na}^{+} / \mathrm{K}^{+}$-ATPase activities. This shift did not affect total gill energy consumption leaving whole animal energy budget unaffected.
\end{abstract}

Communicated by G. Heldmaier.

C. M. Kreiss

Corneliakreiss@gmail.com

1 Alfred Wegener Institute, Helmholtz Center for Marine and Polar Research, Integrative Ecophysiology, Am Handelshafen 12, 27570 Bremerhaven, Germany

2 Department of Biological and Environmental Sciences, University of Gothenburg, PO Box 463, 40530 Gothenburg, Sweden

3 The Sven Lovén Centre for Marine Sciences, Kristineberg 566, 45178 Fiskebäckskil, Sweden
Higher $\mathrm{Na}^{+} / \mathrm{K}^{+}$-ATPase activities in the warmth might have compensated for enhanced branchial permeability and led to reduced plasma $\mathrm{Na}^{+}$and/or $\mathrm{Cl}^{-}$concentrations and slightly lowered osmolalities seen at $18{ }^{\circ} \mathrm{C}$ and 550 or 2200 $\mu$ atm $\mathrm{PCO}_{2}$ in vivo. Overall, the gill as a key ion regulation organ seems to be highly effective in supporting the resilience of cod to effects of ocean warming and acidification.

Keywords $\mathrm{Na}^{+} / \mathrm{K}^{+}$-ATPase $\cdot \mathrm{H}^{+}$-ATPase $\cdot \mathrm{HCO}_{3}{ }^{-}$ transporter $\cdot \mathrm{Na}^{+} / \mathrm{H}^{+}$-exchanger $\cdot$ Standard metabolic rate . Osmolality

\section{Introduction}

Anthropogenic climate change has profound impacts on marine ecosystems as the oceans become warmer and are acidified by the uptake of atmospheric carbon dioxide (Pörtner et al. 2014). Depending on emission scenario atmospheric $\mathrm{PCO}_{2}$ levels are projected to reach between 420 and $940 \mu \mathrm{atm}$ by the year 2100 , consistent with an average decrease in surface ocean $\mathrm{pH}$ by $0.13-0.42$ units. Most of the ocean will continue to warm although rates vary regionally and differ highly between emission scenarios (Collins et al. 2013). Initial studies projected that highly mobile organisms such as marine fishes are excellent osmotic and acid-base regulators and therefore better able to cope with acidification than e.g. more inactive invertebrates with lower ion regulation capacity (Melzner et al. 2009; Wittmann and Pörtner 2013). More recent behavioural studies, mainly of coral reef fish larvae have suggested that some fishes may still be very sensitive when ambient $\mathrm{CO}_{2}$ increases (e.g. Munday et al. 2012; Nilsson et al. 2012; Forsgren et al. 2013). Behavioural effects on sensitive fish species set in at rather low concentrations 
( $<850 \mu$ atm $\mathrm{CO}_{2}$ ); however, the long-term persistence of these phenomena remains to be explored (Wittmann and Pörtner 2013). In fact, Atlantic cod appears resilient to behavioural disturbances at $\mathrm{CO}_{2}$ levels around $1000 \mu \mathrm{atm}$ (Jutfelt and Hedgärde 2013) and up to $4200 \mu$ atm (Maneja et al. 2013). In juvenile cod, aerobic swimming performance was unaffected by exposure to high $\mathrm{PCO}_{2}(3000$ and $6000 \mu \mathrm{atm}$ ) at close to optimum temperatures (Melzner et al. 2009). However, larval stages may be more sensitive. Severe tissue damage was reported for a fraction of the larval offspring of Norwegian coastal cod (Frommel et al. 2011). In contrast, the tissues of early larval stages of Baltic cod remained unaffected up to $3200 \mu \mathrm{atm} \mathrm{PCO}_{2}$ (Frommel et al. 2013). Nonetheless, Atlantic cod avoid hypercapnic water, indicating that elevated $P \mathrm{CO}_{2}$ may have unfavourable effects (Jutfelt and Hedgärde 2013).

More is known about the sensitivity of fish including Atlantic cod to temperature changes (for review see Pörtner et al. 2008; Pörtner and Peck 2010). In cod, the thermal range and associated growth performance characterise populations in a latitudinal cline. The thermal window of performance is wide in juvenile fishes and shrinks with increasing body size, especially due to a weight dependent shift in thermal optima and upper thermal limits to cooler temperatures (Pörtner et al. 2008). The warm-induced decline in performance indicates thermal limitation and has been attributed to the onset of a mismatch between oxygen supply capacity and costs on the one hand and oxygen demand on the other hand, at the so-called pejus temperatures. In common eelpout (Zoarces viviparus) pejus limits were identified to parallel the onset of ecological effect, a loss in field abundance due to warming extremes (Pörtner and Knust 2007). Progressive warming beyond a putative critical limit of $16{ }^{\circ} \mathrm{C}$ caused a sharp drop in venous $\mathrm{PO}_{2}\left(\mathrm{P}_{\mathrm{V}} \mathrm{O}_{2}\right)$, in parallel to the onset of cardiac arrhythmia in cannulated cod (Lannig et al. 2004; it should be noted that cannulation may enhance circulatory cost and cause a downward shift of these limits). As cardiac activity did not compensate for reduced $\mathrm{P}_{\mathrm{V}} \mathrm{O}_{2}$ in the warmth, reduced oxygen supply to tissues and thus decreased aerobic scope of the whole organism above pejus limits was proposed as the first level of thermal limitation (Lannig et al. 2004; Pörtner et al. 2004). Thermal constraints may affect the scope of energy dependent mechanisms sustaining homeostasis, such as ion and acid-base regulation, and their share in energy budget, especially if challenged by ocean acidification. These changes may feedback on thermal tolerance.

Water breathers exposed to elevated $\mathrm{PCO}_{2}$ in seawater need to re-establish acid-base equilibria through proton equivalent ion exchange. In marine fish, ion regulation mainly takes place in the gills causing a net uptake of bicarbonate within 20-30 min, varying with the extent of acid-base disturbance (Evans et al. 2005). Membrane proteins, including $\mathrm{Na}^{+} / \mathrm{H}^{+}$-exchangers, V-type $\mathrm{H}^{+}$ATPase, $\mathrm{HCO}_{3}{ }^{-}$-transporters and $\mathrm{Na}^{+} / \mathrm{HCO}_{3}$ co-transporters contribute to these processes and have associated energetic costs (e.g. Claiborne et al. 2002; Deigweiher et al. 2008; Heuer and Grosell, 2014). Many studies have focused on the identification and localization of the proteins involved in acid-base regulation applying immunological and molecular techniques, while knowledge of in vivo usage of specific transporter and associated metabolic costs is scarce. In branchial tissue, $\mathrm{Na}^{+} / \mathrm{K}^{+}$-ATPase is generally thought to be the key transporter driving most energy dependent ion transport processes including those related to acid-base regulation (Deigweiher et al. 2008). An upregulation of this important transport protein, determined via analyses of activity in isolated gills or of enzyme capacity in crude gill homogenates in cod, notothenioids, and eelpout gills was observed under $\mathrm{CO}_{2}$ concentrations of $>6000 \mu \mathrm{atm}$; ranging from acute exposure to up to 1 year of acclimation (Deigweiher et al. 2008; Melzner et al. 2009; Deigweiher et al. 2010). In contrast, cod acclimated long term to moderately elevated $\mathrm{PCO}_{2}(2500 \mu$ atm $)$ revealed reduced branchial energy turnover in vivo at unchanged in vitro $\mathrm{Na}^{+} / \mathrm{K}^{+}$-ATPase capacity (Kreiss et al. 2015).

Here we conducted a follow-up experiment with transporter specific inhibitors in order to identify the mechanisms contributing to acid-base regulation. We exposed Atlantic cod from the Kattegat/Skagerrak to different levels of $\mathrm{PCO}_{2}$ and temperature for 4 weeks. Atlantic cod is expected to experience strong anthropogenic climate change (Drinkwater 2005), as its habitat on the European Shelf is estimated to undergo one of the highest rates of change in seasonal temperature maxima and minima (Taboada and Anadón 2012). The North Sea region might also exceed the globally predicted average of acidification and reach $1000 \mu \mathrm{atm} \mathrm{CO}_{2}$ already around the year 2060 (Blackford and Gilbert 2007). In our experiments, we used $10{ }^{\circ} \mathrm{C}$ as the optimum temperature, which is close to average habitat temperature and represents the maximum growth temperature of young adults of this species (Pörtner et al. 2008). For the high temperature treatment, we chose $18{ }^{\circ} \mathrm{C}$ as this is well in the range of maximum summer values experienced by Atlantic cod (Neat and Righton 2007; Righton et al. 2010). $\mathrm{PCO}_{2}$ levels were selected to cover present and future natural variability at the study site: 550 $\mu$ atm was chosen as a low value, $1200 \mu$ atm as a medium and $2200 \mu \mathrm{atm}$ as a high $\mathrm{CO}_{2}$ partial pressure. Seawater $\mathrm{PCO}_{2}$ in the Atlantic in general is characterised by a seasonal cycle with surface waters being oversaturated during winter, summer and autumn, while being undersaturated during spring (Takahashi et al. 1993; Gypens et al. 2011). $\mathrm{PCO}_{2}$ also increases in parallel to seasonal temperature. We hypothesise that the combination of elevated temperature and $\mathrm{PCO}_{2}$ will affect the energy demand at whole 
animal level, as a consequence of shifts in ion regulation and associated energy (re)allocation. We also hypothesise that changes in branchial $\mathrm{Na}^{+} / \mathrm{K}^{+}$-ATPase usage under high $\mathrm{PCO}_{2}$ and/or temperature will reflect altered activities of other ion transporters and lead to altered plasma ionic status.

\section{Materials and methods}

Experiments using live animals were approved according to ethical commission Dnr.: 23-2012, Sweden's Ethical Committee on Animal Experiments.

\section{Experimental animals}

Atlantic cod Gadus morhua of mixed gender (200.52 \pm 95.4 g FW) were caught in fish traps in the Gullmarfjord around the Sven Lovén Centre for Marine Sciences-Kristineberg (Fiskebäckskil, Sweden) in February/ March 2012 (permission: Dnr.: 3157-11). At the Marine Station, the fish were held for 2-3 weeks in 12001 tanks with natural flowing seawater at $10{ }^{\circ} \mathrm{C}$. For the experiments, fish were tagged individually (Visible Implant Elastomer, Northwest Marine Technology Inc. Washington, USA) while anaesthetized with MS-222 (3-aminobenzoic ethyl ester, Applichem, Darmstadt; Germany) at a concentration of $0.2 \mathrm{~g} / \mathrm{l}$. Afterwards animals were exposed for 4 weeks to $10.3 \pm 0.2{ }^{\circ} \mathrm{C}$ and $18.1 \pm 0.2{ }^{\circ} \mathrm{C}$ at $553 \pm 78$ $\mu \mathrm{atm} \mathrm{CO}_{2}, 1470 \pm 460 \mu \mathrm{atm} \mathrm{CO}_{2}$ and $2228 \pm 312 \mu \mathrm{atm}$ $\mathrm{CO}_{2}$ (Table 1). These values encompassed the range of interannual $\mathrm{PCO}_{2}$ fluctuations reported for the Gullmarsfjord from 500 to $1000 \mu \mathrm{atm}$, paralleled by $\mathrm{pH}$ oscillations of about 0.15 between $10{ }^{\circ} \mathrm{C}$ (more alkaline) and $18{ }^{\circ} \mathrm{C}$ (more acidified, Swedish Oceanographic Data Centre (SODC), pH data recorded in the Gullmarsfjord from 1921 to 1989 , recalculated by S. Dupont). 8-10 fish were incubated per 12001 tank, with two replicate tanks per treatment. Fish in the high temperature treatment were directly exposed to $18{ }^{\circ} \mathrm{C}$ without gradual warming. $\mathrm{CO}_{2}$-partial pressures of 1200 and $2200 \mu$ atm equivalent to $\mathrm{pH} 7.7$ and 7.5 were maintained by a computerised feedback system (Aqua Medic GmbH, Bissendorf, Germany), which regulates $\mathrm{pH}$ (NBS scale) by addition of gaseous $\mathrm{CO}_{2}$ to the seawater tank ( $\pm 0.02 \mathrm{pH}$ units). Fish reared at low $\mathrm{PCO}_{2}$ were maintained in aerated natural seawater. To ensure a consistent mixture of the water, mass pumps with a power of $40 \mathrm{l}$ 1/min (Eheim GmbH, Deizisau, Germany) were inserted in the tanks. The cod were fed three times a week until satiation with frozen shrimp and blue mussels and were maintained under a 12:12 day: night cycle. Animals were starved for $48 \mathrm{~h}$ prior to preparation and experiments. Water chemistry was controlled twice a week by measuring $\mathrm{pH}$ and temperature (portable $\mathrm{pH}$ metre Profi line $\mathrm{pH}$ 3310, WTW GmbH, Weilheim, Germany, NIST Scale corrected to total scale via Dickson standards). Total alkalinity was measured photometrically with an accuracy of $10 \mu \mathrm{mol} / \mathrm{kg}^{-1}$ seawater according to Sarazin et al. (1999). For total dissolved inorganic carbon (DIC), an autoanalyser (SFA QuAAtro 800 TM, SEAL, Wisconsin, USA) was used; salinity was measured with a conductivity metre (Cond 1970i, WTW GmbH, Weilheim, Germany). $\mathrm{PCO}_{2}$ values were calculated using the $\mathrm{CO}_{2}$ sys programme [constants of Mehrbach et al. (1973); refitted by Dickson and Millero (1987) developed by Lewis and Wallace (1998) (Table 1)].

Table 1 Water parameters of different treatments during animal incubation with two replicates each (1 and 2)

\begin{tabular}{|c|c|c|c|c|c|c|}
\hline Parameter & Low tank 1 & Low tank 2 & Medium tank 1 & Medium tank 2 & High tank 1 & High tank 2 \\
\hline Temperature & $10.6 \pm 0.2$ & $10.4 \pm 0.2$ & $10.3 \pm 0.1$ & $10.1 \pm 0.1$ & $10.3 \pm 0.2$ & $10.1 \pm 0.1$ \\
\hline$P \mathrm{PO}_{2}[\mu \mathrm{atm}]$ & $504.36 \pm 54.52$ & $488.51 \pm 52.42$ & $1151.00 \pm 120.78$ & $1111.84 \pm 75.67$ & $2184.54 \pm 338.4$ & $2131.62 \pm 317.7$ \\
\hline pH (NBS scale) & $8.13 \pm 0.03$ & $8.13 \pm 0.03$ & $7.76 \pm 0.02$ & $7.74 \pm 0.03$ & $7.50 \pm 0.06$ & $7.50 \pm 0.03$ \\
\hline pH (total scale) & $7.97 \pm 0.04$ & $7.98 \pm 0.04$ & $7.65 \pm 0.02$ & $7.63 \pm 0.04$ & $7.37 \pm 0.06$ & $7.38 \pm 0.04$ \\
\hline Salinity [PSU] & $32.6 \pm 0.3$ & $32.6 \pm 0.2$ & $32.6 \pm 0.5$ & $32.5 \pm 0.5$ & $32.6 \pm 0.2$ & $32.6 \pm 0.2$ \\
\hline $\mathrm{DIC}[\mu \mathrm{mol} / \mathrm{L}]$ & $2325.5 \pm 65.6$ & $2297.1 \pm 42.9$ & $2363.9 \pm 31.4$ & $2373.6 \pm 66.2$ & $2495.0 \pm 90.0$ & $2325.5 \pm 65.6$ \\
\hline Alkalinity & $2326.4 \pm 68.9$ & $2337.0 \pm 44.9$ & $2330.2 \pm 34.5$ & $2327.8 \pm 24.2$ & $2329.6 \pm 28.8$ & $2327.4 \pm 29.8$ \\
\hline Temperature & $17.9 \pm 0.2$ & $18.0 \pm 0.1$ & $18.2 \pm 0.1$ & $18.1 \pm 0.1$ & $18.2 \pm 0.2$ & $18.2 \pm 0.1$ \\
\hline$P \mathrm{PO}_{2}[\mu \mathrm{atm}]$ & $595.94 \pm 59.75$ & $623.08 \pm 50.30$ & $1278.01 \pm 80.16$ & $1305.32 \pm 82.96$ & $2366.74 \pm 340.3$ & $2214.85 \pm 229.4$ \\
\hline pH (NBS scale) & $8.04 \pm 0.05$ & $8.02 \pm 0.01$ & $7.77 \pm 0.02$ & $7.76 \pm 0.02$ & $7.50 \pm 0.06$ & $7.53 \pm 0.05$ \\
\hline pH (total scale) & $7.91 \pm 0.03$ & $7.89 \pm 0.03$ & $7.61 \pm 0.02$ & $7.60 \pm 0.02$ & $7.36 \pm 0.06$ & $7.39 \pm 0.04$ \\
\hline Salinity [PSU] & $32.0 \pm 1.2$ & $32.0 \pm 1.0$ & $32.6 \pm 0.3$ & $32.6 \pm 0.3$ & $32.0 \pm 1.1$ & $32.1 \pm 1.0$ \\
\hline $\mathrm{DIC}[\mu \mathrm{mol} / \mathrm{l}]$ & $2296.5 \pm 58.5$ & $2279.4 \pm 44.9$ & $2338.7 \pm 4.1$ & $2364.5 \pm 66.2$ & $2370.7 \pm 62.4$ & $2390.2 \pm 81.2$ \\
\hline Alkalinity & $2326.0 \pm 41.4$ & $2315.0 \pm 32.7$ & $2326.0 \pm 28.0$ & $2334.0 \pm 30.0$ & $2324.7 \pm 38.8$ & $2326.6 \pm 38.9$ \\
\hline
\end{tabular}




\section{Oxygen consumption of whole fish}

Standard metabolic rate $\left(\mathrm{MO}_{2 \min }\right)$ of Atlantic cod was measured by intermittent-flow respirometry of individual fish (six measured in parallel) starting after 3 weeks of experimental exposure of 12 fish per treatment (including six fish from each replicate tank). The fish were starved for $48 \mathrm{~h}$ in their exposure tanks before placing them into the respirometer, a custom-built sealed 31 horizontal cylindrical acrylic respirometer with a circulation pump (5 1/min) (Eheim GmbH \& Co., Deizisau Germany), equipped with an in-line robust $3 \mathrm{~mm}$ oxygen optode (FireSting, Pyroscience, Aachen, Germany). The optode was connected to the optical oxygen meter $\left(\right.$ FireSting $\left.\mathrm{O}_{2}\right)$ which in turn was connected to a PC running the Pyro Oxygen Logger (FireSting Pyroscience, Aachen, Germany). The fish were kept undisturbed in the respirometer for $48 \mathrm{~h}$ with continuous 20 min measurements followed by $10 \mathrm{~min}$ of flushing, controlled by a timer. The $\mathrm{O}_{2}$ saturation in the respirometers was always above $80 \%$. The mean of the lowest $10 \%$ of recorded $\mathrm{MO}_{2}$ values is presented as standard metabolic rate, calculated as $\mathrm{M}\left(\mathrm{O}_{2}\right)=\left[\mu \mathrm{mol}\left(\mathrm{O}_{2}\right) \times \mathrm{gFW}^{-1} \times \mathrm{h}^{-1}\right]$. During respirometry of fish at $18{ }^{\circ} \mathrm{C}$ and low $\mathrm{PCO}_{2}$, two fish died from asphyxiation due to water pump failure interrupting the flow. Whole animal as well as gill oxygen consumption rates of the remaining fish from the same tank were significantly reduced compared to the replicate tank. As we cannot preclude that the fish released chemical alarm signals in response to hypoxia (Lebedeva et al. 1994) or excreted catecholamines (Butler et al. 1989), which might induce decreased metabolism (Wahlquivst and Nilsson 1977), we excluded the respective data from further analyses. In later studies, all fish subjected to respiration protocols displayed parameters such as blood ion concentration and osmolality or those investigated in isolated gill experiments identical to those not exposed to respirometry.

\section{Animals and isolated gill preparation}

Fish were anaesthetised with $0.2 \mathrm{~g} / \mathrm{l} \mathrm{MS} 222$ and identified by the tag. Blood samples were taken from the ventral vein for later analysis of osmolality and ionic composition. Subsequent to killing the animals by cutting their spine, gill arches were quickly dissected. The first two arches from each side of five fish (10 per treatment and replicate) were used for experiments and immediately placed in ice-cold saline. They were cleared from blood by use of a syringe flushing the efferent blood vessel with saline containing heparin $(5000 \mathrm{U} / \mathrm{l})$. The preparation of isolated gill arches was conducted according to Kreiss et al. 2015. Gill arches were suspended by their perfusion tubing attached to the chamber lid, while a magnetic stir bar within the chamber ensured constant mixing of the respiratory medium. The perfusion saline was prepared according to Holmgren and Nilsson (1974) with the exception of $\mathrm{HCO}_{3}$, which was calculated after Heisler $(1984,1986)$ according to Kreiss et al. $2015\left(10{ }^{\circ} \mathrm{C}, 550 \mu\right.$ atm $P_{C O}: 11.50 \mathrm{mM} ; 10{ }^{\circ} \mathrm{C}, 1200 \mu \mathrm{atm}$ $P \mathrm{CO}_{2}: 14.00 \mathrm{mM} ; 10{ }^{\circ} \mathrm{C}, 2200 \mu$ atm $P \mathrm{PO}_{2}: 16.18 \mathrm{mM}$; $18{ }^{\circ} \mathrm{C}, 550 \mu$ atm $P \mathrm{PO}_{2}: 7.11 \mathrm{mM} ; 18{ }^{\circ} \mathrm{C}, 1200 \mu$ atm $P \mathrm{PO}_{2}$ : $8.63 \mathrm{mM} ; 18^{\circ} \mathrm{C} 2200 \mu$ atm $\left.P \mathrm{CO}_{2}: 10.00 \mathrm{mM}\right)$.

The $\mathrm{pH}$ of the Ringer solution was adjusted by a computerized feedback system using gaseous $\mathrm{CO}_{2}$ (Aqua medic GmbH Bissendorf, Germany) to $7.95 \pm 0.05$ for treatments at $10{ }^{\circ} \mathrm{C}$ and to $7.88 \pm 0.07$ for treatments at $18{ }^{\circ} \mathrm{C}$. Seawater for respiration measurements was equilibrated with a membrane pump (Schemel \& Goetz \& Co KG, Offenbach, Germany) and reached $\mathrm{pH}=8.09 \pm 0.06$ at $10{ }^{\circ} \mathrm{C}$ and low $\mathrm{PCO}_{2}$ and $\mathrm{pH}=8.09 \pm 0.06$ at $18{ }^{\circ} \mathrm{C}$ and low $P^{\circ} \mathrm{CO}_{2}$. Equilibration with defined gas mixtures (AGA gas $\mathrm{AB}$, Sweden) led to $\mathrm{pH}$ values matching the desired levels of $\mathrm{PCO}_{2}$ $\left(10{ }^{\circ} \mathrm{C}\right.$, medium $(1200 \mu \mathrm{atm}): 7.74 \pm 0.01 ; 10{ }^{\circ} \mathrm{C}$, high (2200 $\mu \mathrm{atm}): 7.52 \pm 0.02 ; 18{ }^{\circ} \mathrm{C}$, medium: $7.75 \pm 0.01$; $18{ }^{\circ} \mathrm{C}$, high: $7.55 \pm 0.03$ ).

\section{Energy budget of branchial ion transporters}

Gill respiration was analysed according to Kreiss et al. (2015). In brief, the oxygen uptake of isolated perfused gill arches from the respiratory medium (seawater with incubation equivalent $\mathrm{CO}_{2}$ levels) was measured in thermostated $\left(10\right.$ or $18{ }^{\circ} \mathrm{C}$ ) chambers, by use of oxygen micro-optodes (needle type, $140 \mu \mathrm{m}$, PreSens, Regensburg, Germany). Fractional respiratory costs of branchial ion transporters were investigated via inhibitors for $\mathrm{Na}^{+} / \mathrm{K}^{+}$-ATPase (ouabain), $\mathrm{H}^{+}$-ATPase (bafilomycin $\mathrm{A} 1$ ), $\mathrm{Na}^{+} / \mathrm{H}^{+}$-exchanger $\left\{[5\right.$-( $N$-ethyl- $N$-isopropyl) amiloride] (EIPA) $\}$ and $\mathrm{HCO}_{3}{ }^{-}$transporter [4,4'-Diisothiocyano-2,2'stilbenedisulfonic acid (DIDS)] applied to the respiratory medium following earlier methodological improvements (Kreiss et al. 2015). Transport inhibitors (obtained from Applichem, Darmstadt, Germany or Sigma-Aldrich, Taufkirchen, Germany) were dissolved in DMSO at a final DMSO concentration of less than $1 \%$, which had no effect on respiration in control experiments (data not shown). Final concentrations of inhibitors were in the range of literature values: ouabain $5 \mathrm{mM}$ (Krumschnabel and Wieser 1994; Mark et al. 2005) bafilomycin A1 $0.1 \mu \mathrm{M}$ (Morgan and Iwama 1999; Pörtner et al. 2000), EIPA $80 \mu \mathrm{M}$ (Wu et al. $2010(100 \mu \mathrm{M})$ ) and DIDS 1 mM (Duraton et al. 1997; Parks et al. 2007). Each gill arch was used as its own control prior to application of one inhibitor. Control and inhibitor experiments were conducted for a period of $45 \mathrm{~min}$ each while recording oxygen consumption. After experimentation, the gill arches were separated from tubing and blotted dry for determining their total weight. Soft tissue was isolated and weighed after cutting as close as possible to the arch. For each of 
the six treatments and for each inhibitor, a set of ten gill arches from ten individual fish (five per replicate tank) were measured. Oxygen consumption rates were normalised to soft tissue weight (without the cartilaginous arch) as $\mathrm{M}\left(\mathrm{O}_{2}\right)=\left[\mu \mathrm{mol}\left(\mathrm{O}_{2}\right) \times \mathrm{gFW}^{-1} \times \mathrm{h}^{-1}\right]$.

\section{Osmolality and ion composition}

Blood was centrifuged for $10 \mathrm{~min}$ at $1000 \mathrm{~g}$ and $4{ }^{\circ} \mathrm{C}$. Osmolality was measured in the resultant plasma with a Vapour Pressure Osmometer (Wescor Inc., Utah, USA). Ion composition was determined chromatographically. $\mathrm{Na}^{+}$concentration was analysed amongst other cations by use of an Ion Chromatography System (DIONEX-ICS 2000, CA, USA) at $40{ }^{\circ} \mathrm{C}$ including an IonPac CS 16 column, with methane sulfonic acid $(30 \mathrm{mM})$ as eluent at $0.36 \mathrm{ml} \mathrm{min}^{-1}$ flow rate. Cation concentrations were calculated according to a cation standard (Dionex, Six Cation Standard, CA, USA). Anions were separated on an Ion Pac AS11HC column with potassium hydroxide $(30 \mathrm{mM}$, flow rate $0.30 \mathrm{ml} \mathrm{min}{ }^{-1}$ ) as an eluent. Dionex Five Anion Standard was used as a reference to calculate anion concentrations. All ion concentrations are presented as $\mathrm{mM}$. Plasma total $\mathrm{CO}_{2}\left(\mathrm{CCO}_{2}\right)$ of two treatment groups $\left[10^{\circ} \mathrm{C}\right.$, medium
$\mathrm{PCO}_{2}(n=4) ; 18{ }^{\circ} \mathrm{C}$, high $\left.P \mathrm{PO}_{2},(n=46)\right]$ was determined with a carbon dioxide analyser (Corning 965, CIBA, Corning diagnostics, UK). Plasma bicarbonate levels were calculated from total $\mathrm{CO}_{2}$ by subtracting physically dissolved $\mathrm{CO}_{2}$ adopting ambient $P \mathrm{PO}_{2}$ levels.

\section{Data analysis and statistics}

Statistical analysis was performed using Sigma plot 12.0 and Graphpad Prism 4. Seawater chemistry was tested for differences between $\mathrm{PCO}_{2}$, temperature and replicate tanks performing repeated measures two-way ANOVAs with subsequent Sidak's multiple comparison tests (Table 2). All data are depicted as mean \pm standard error. Outliers at a $99 \%$ confidence level were identified using Nalimov's test and removed from the plasma data set. Means of plasma ion concentrations, SMR, net $\mathrm{O}_{2}$ demands of isolated perfused gills and of $\mathrm{HCO}_{3}{ }^{-}$-transporter were compared using two-way ANOVAs with subsequent Tukey multiple comparison tests (Table 3). Osmolality, net $\mathrm{O}_{2}$ demand determined in the remaining isolated gill inhibitor experiments (of $\mathrm{Na}^{+} / \mathrm{K}^{+}$-ATPase, $\mathrm{Na}^{+} / \mathrm{H}^{+}$-exchanger, $\mathrm{H}^{+}$-ATPase) as well as the fractional weight of gill soft tissue were not normally distributed and therefore compared via one-way

Table 2 Results of repeated measures two-way ANOVAs performed to investigate potential differences between acclimation conditions $\left(\mathrm{PCO}_{2}\right.$; temperature levels) and replicate tanks within and between

these treatments (low $\mathrm{PCO}_{2}=550 \mu$ atm; medium $\mathrm{PCO}_{2}=1200$ $\mu$ atm and high $\mathrm{PCO}_{2}=2200 \mu$ atm at $10^{\circ} \mathrm{C} ; 18^{\circ} \mathrm{C}$ )

\begin{tabular}{|c|c|c|c|c|c|c|c|c|c|c|c|c|}
\hline \multirow[t]{2}{*}{ Variable } & \multicolumn{3}{|c|}{$\mathrm{PCO}_{2}$ effect } & \multicolumn{3}{|c|}{ Temperature effect } & \multicolumn{3}{|c|}{ Replicate effect } & \multicolumn{3}{|c|}{ Interaction } \\
\hline & $F$ & $d F$ & $P$ & $F$ & $d F$ & $P$ & $F$ & $d F$ & $P$ & $F$ & $d F$ & $P$ \\
\hline $\mathrm{PCO}_{2}$ & 1446 & 2 & $<0.0001$ & - & - & - & 6.208 & 3 & 0.007 & 2.241 & 6 & 0.045 \\
\hline Temperature & - & - & - & 39.060 & 1 & $<0.0001$ & 0.4647 & 1 & 0.4970 & 0.0064 & 1 & 0.6951 \\
\hline Low $\mathrm{PCO}_{2}$ & - & - & - & 34.61 & 1 & $<0.0001$ & 0.0864 & 1 & 0.7709 & 1.251 & 1 & 0.2729 \\
\hline Medium $\mathrm{PCO}_{2}$ & - & - & - & 26.29 & 1 & $<0.0001$ & 0.0008 & 1 & 0.9765 & 0.7693 & 1 & 0.3879 \\
\hline High $P \mathrm{CO}_{2}$ & - & - & - & 1.593 & 1 & 0.5697 & 1.067 & 1 & 0.3105 & 0.5697 & 1 & 0.3309 \\
\hline $10^{\circ} \mathrm{C}$ & 307.8 & 2 & $<0.0001$ & - & - & - & 0.2700 & 1 & 0.6115 & 0.0385 & 2 & 0.9623 \\
\hline $18{ }^{\circ} \mathrm{C}$ & 352.9 & 2 & $<0.0001$ & - & - & - & 0.462 & 1 & 0.5078 & 1.838 & 2 & 0.1778 \\
\hline
\end{tabular}

Significant differences are presented in bold

Table 3 Results of two-way ANOVAs performed to investigate potential differences of SMR, plasma ion concentrations and gill oxygen consumption between differently exposed fish groups (low $P \mathrm{CO}_{2}=550 \mu \mathrm{atm}$; medium $\mathrm{PCO}_{2}=1200 \mu$ atm and high $\mathrm{PCO}_{2}=2200 \mu \mathrm{atm}$ at $10^{\circ} \mathrm{C} ; 18^{\circ} \mathrm{C}$ )

\begin{tabular}{|c|c|c|c|c|c|c|c|c|c|}
\hline \multirow[t]{2}{*}{ Variable } & \multicolumn{3}{|c|}{$\mathrm{PCO}_{2}$ effect } & \multicolumn{3}{|c|}{ Temperature effect } & \multicolumn{3}{|c|}{ Interaction } \\
\hline & $F$ & $d F$ & $P$ & $F$ & $d F$ & $P$ & $F$ & $d F$ & $P$ \\
\hline SMR & 0.0931 & 2 & 0.911 & 16.36 & 1 & 0.0002 & 2.383 & 2 & 0.1025 \\
\hline Plasma $\mathrm{Na}^{+}$ & 0.318 & 2 & 0.729 & 19.298 & 1 & $<0.001$ & 6.535 & 2 & 0.003 \\
\hline Plasma Cl$^{-}$ & 3.803 & 2 & 0.027 & 3.642 & 1 & 0.060 & 9.024 & 2 & $<0.001$ \\
\hline Gill $\mathrm{MO}_{2}$ & 0.9367 & 2 & 0.393 & 89.33 & 1 & $<0.0001$ & 0.1381 & 2 & 0.8711 \\
\hline $\mathrm{HCO}_{3}{ }^{-}$-transporter & 7.871 & 2 & 0.001 & 4.297 & 1 & 0.043 & 2.287 & 2 & 0.112 \\
\hline
\end{tabular}

Significant differences are presented in bold 
Table 4 Results of one-way ANOVAs, respectively, Kruskal-Wallis one-way ANOVAs performed to investigate potential differences of osmolality and ion transporter net $\mathrm{O}_{2}$ demand from iso- lated gill experiments between differently exposed fish groups (low $P C_{2}=550 \mu$ atm; medium $P C O_{2}=1200 \mu$ atm and high $\left.\mathrm{PCO}_{2}=2200 \mu \mathrm{atm}\right)$ at $10{ }^{\circ} \mathrm{C}$, respectively, $18{ }^{\circ} \mathrm{C}$

\begin{tabular}{|c|c|c|c|c|c|c|}
\hline \multirow[t]{2}{*}{ Variable } & \multicolumn{3}{|l|}{$10^{\circ} \mathrm{C}$} & \multicolumn{3}{|l|}{$18^{\circ} \mathrm{C}$} \\
\hline & $F$ & $d F$ & $P$ & $F$ & $d F$ & $P$ \\
\hline Osmolality & 0.02401 & 2 & 0.9763 & 6.775 & 2 & 0.0032 \\
\hline $\mathrm{Na}^{+} / \mathrm{K}^{+}$-ATPase & 0.878 & 2 & 0.428 & $\mathrm{H}=1.355$ & 2 & 0.508 \\
\hline $\mathrm{H}^{+}$-ATPase & 0.347 & 2 & 0.710 & 0.592 & 2 & 0.560 \\
\hline $\mathrm{Na}^{+} / \mathrm{H}^{+}$-exchanger & 4.025 & 2 & $\mathbf{0 . 0 3 0}$ & 6.064 & 2 & 0.007 \\
\hline$\%$ Gill filament weight & $H=14.96$ & 2 & $<0.001$ & $\mathrm{H}=1.561$ & 2 & 0.458 \\
\hline
\end{tabular}

$H$ value instead of $F$ value is given when non-parametric Kruskal-Wallis test was performed

Significant differences are presented in bold

ANOVAs or Kruskal-Wallis non-parametric ANOVAs per temperature (Table 4). To test for differences between $\mathrm{CO}_{2}$ concentrations within these datasets, subsequent unpaired $t$ tests with Holm-Bonferroni correction was used. Gill total respiration as the fraction of standard metabolic rate of whole fish (\%) was compared within treatments at $10{ }^{\circ} \mathrm{C}$ performing a one-way ANOVA, while Holm-Bonferroni corrected unpaired $t$ tests were conducted to detect differences between all treatments. Differences between remaining treatments were also tested via unpaired $t$ tests except for the two low $\mathrm{PCO}_{2}$ groups where only means of gill and whole animal respiration could be compared for low $\mathrm{PCO}_{2}$ fish at $18{ }^{\circ} \mathrm{C}$, due to low $n$ numbers at $18{ }^{\circ} \mathrm{C}$. A significance level of $p<0.05$ was adopted for all data. $Q_{10}$ values were calculated for the mean net oxygen demand of the four transporters investigated in the groups exposed to 10 and $18{ }^{\circ} \mathrm{C}$ and the respective $P^{\circ} \mathrm{CO}_{2}$ levels. Unfortunately, fish from the two tanks at $18{ }^{\circ} \mathrm{C}$ and low $P \mathrm{CO}_{2}$ could not be clearly assigned to their original tank as these were accidently mixed after respiration experiments. For the remaining groups, we performed $t$ tests to detect potential differences between replicates. Except for the standard metabolic rates of the two groups at low $\mathrm{PCO}_{2}$ and $18{ }^{\circ} \mathrm{C}$ (see above) no differences in any of the tested parameters were detected between fish groups from replicate tanks.

\section{Results}

\section{Seawater chemistry and mortality}

Seawater chemistry and temperatures of the 12 tanks are summarised in Table 1. $P_{C O}$ and temperature differed significantly $(p<0.0001)$ between tanks according to experimental conditions (Table 2). Statistical interactions found for $\mathrm{PCO}_{2}$ replicates are explained by differences between data measured at 10 and $18{ }^{\circ} \mathrm{C}$. In general, $\mathrm{PCO}_{2}$ values calculated for $18{ }^{\circ} \mathrm{C}$ were above those found at $10{ }^{\circ} \mathrm{C}$
(Table 1). This was especially pronounced for the low and medium $\mathrm{PCO}_{2}$ groups (Table 2), however, the difference of approximately $100 \mu \mathrm{atm}$ was considered negligible from a physiological view. Tank replicates did not differ between any treatment neither for temperature nor for $\mathrm{PCO}_{2}$ levels (Table 2). For $\mathrm{PCO}_{2}$ treatments at 10 and $18{ }^{\circ} \mathrm{C}$, replicates were maximally $\pm 0.5^{\circ}$ different $(p<0.0001)$. This difference might be explained by a slight temperature gradient within the rooms and was considered minor.

Total mortality during incubation was $8.2 \%$ (nine fish); however, almost half of the casualties (four fish) were found at $18{ }^{\circ} \mathrm{C}$ and low $\mathrm{PCO}_{2}$, while other losses were evenly distributed between exposure groups. Furthermore, two fish died of asphyxiation (see above) and one animal died from the consequences of jumping out of the tank, leaving us with a total of 99 fish.

\section{Oxygen consumption of whole animals}

Mean standard metabolic rates related to body mass were in the same range for fish reared at low $\mathrm{PCO}_{2}$ and both incubation temperatures $\left(10{ }^{\circ} \mathrm{C}: 2.31 \pm 0.64 \mu \mathrm{mol}\right.$ $\mathrm{O}_{2} \times \mathrm{gFW}^{-1} \times \mathrm{h}^{-1} ; 18{ }^{\circ} \mathrm{C}: 2.67 \pm 0.04 \mu \mathrm{mol}$ $\mathrm{O}_{2} \times \mathrm{h}^{-1} \times \mathrm{gFW}^{-1}$ ) (Fig. 1). Increasing $\mathrm{CO}_{2}$ levels influenced metabolic rate differently depending on incubation temperature (Fig. 1). Significant differences between groups at the two temperatures were observed at either medium or high $\mathrm{PCO}_{2}$ when the fish reared at $18{ }^{\circ} \mathrm{C}$ displayed a higher SMR than those acclimated to $10{ }^{\circ} \mathrm{C}$ $\left(p=0.043\right.$ at medium $P_{2} ; p<0.0001$ at high $P_{2} \mathrm{CO}_{2}$ ).

\section{Plasma osmolality and ion concentrations}

Plasma osmolality (Fig. 2) was independent of $\mathrm{CO}_{2}$ in cod reared long term at $10{ }^{\circ} \mathrm{C}$ (optimum temperature, total mean $\left.354.53 \pm 31.52 \mathrm{mmol} \mathrm{kg}{ }^{-1}\right)$. It was significantly lower in cod at $18{ }^{\circ} \mathrm{C}$ under low and high $\mathrm{CO}_{2}$ compared to fish reared at $18{ }^{\circ} \mathrm{C}$ and medium $\mathrm{PCO}_{2}(p<0.05)$. No 


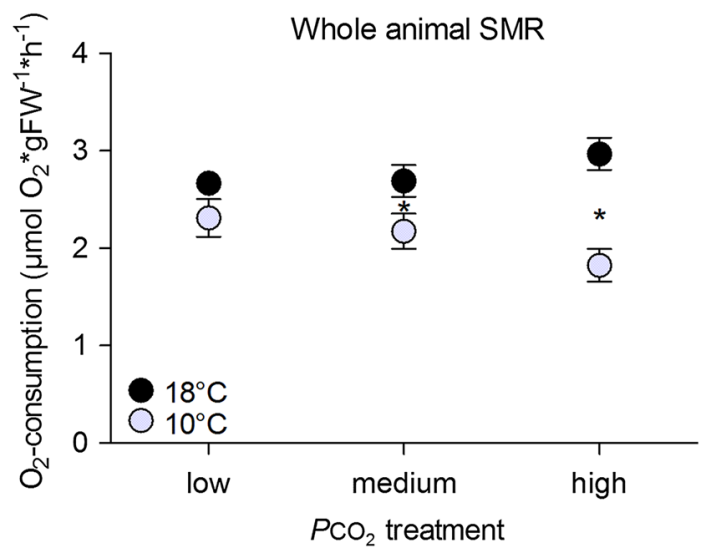

Fig. 1 Standard metabolic rate $\left(\mu \mathrm{mol} \mathrm{O}_{2} \times \mathrm{gFW}^{-1} \times \mathrm{h}^{-1}\right)$ of cod 4 weeks exposed to low $P_{C O}=550 \mu$ atm (L), medium $P \mathrm{PO}_{2}=1200 \mu \mathrm{atm}(\mathrm{M})$ and high $P \mathrm{PO}_{2}=2200 \mu \mathrm{atm}(\mathrm{H})$ at $10{ }^{\circ} \mathrm{C}$ (grey circles) and at $18{ }^{\circ} \mathrm{C}$ (black circles). $n=4-12$ per treatment. Symbols indicate significant differences between temperature groups $(p<0.05)$

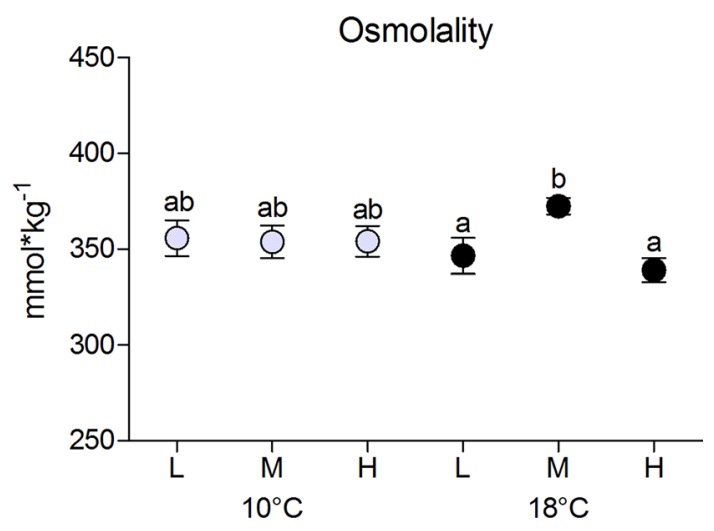

Fig. 2 Plasma osmolality $\left(\mathrm{mmol} \mathrm{kg}{ }^{-1}\right)$ of cod 4 weeks exposed to low $P_{C O}=550 \mu$ atm $(\mathrm{L})$, medium $P \mathrm{PCO}_{2}=1200 \mu \mathrm{atm}(\mathrm{M})$ and high $\mathrm{PCO}_{2}=2200 \mu \mathrm{atm}(\mathrm{H})$ at $10{ }^{\circ} \mathrm{C}$ (grey circles) and at $18{ }^{\circ} \mathrm{C}$ (black circles). $n=18-20$ per treatment. Different letters indicate significant differences between treatment groups $(p<0.05)$

statistical temperature effect was detected between fish reared at $10{ }^{\circ} \mathrm{C}$ and $18{ }^{\circ} \mathrm{C}$. Plasma ion concentrations (Fig. 3a, b) at low $\mathrm{PCO}_{2}$ and $10{ }^{\circ} \mathrm{C}$ were in the range of $188 \pm 16 \mathrm{mM}$ for $\mathrm{Na}^{+}$, and $175 \pm 21 \mathrm{mM}$ for $\mathrm{Cl}^{-}$(Fig. 3a, b). For fish at $10{ }^{\circ} \mathrm{C}$, both ions were found at $\sim 10 \%$ lower concentrations at medium $\mathrm{PCO}_{2}$ than under low $\mathrm{PCO}_{2}$ $\left(p=0.057 \mathrm{Na}^{+}, p=0.025 \mathrm{Cl}^{-}\right)$. At $10{ }^{\circ} \mathrm{C}$ and high $\mathrm{PCO}_{2}, \mathrm{Cl}^{-}$concentrations fell below values of animals at low $\mathrm{PCO}_{2}(15 \% ; p=0.004)$; whereas $\mathrm{Na}^{+}$plasma levels were only marginally reduced $(3 \%)$. Plasma bicarbonate for the medium $\mathrm{PCO}_{2}$ group at $10{ }^{\circ} \mathrm{C}$ was in the range of $10.99 \pm 0.69 \mathrm{mM}$.

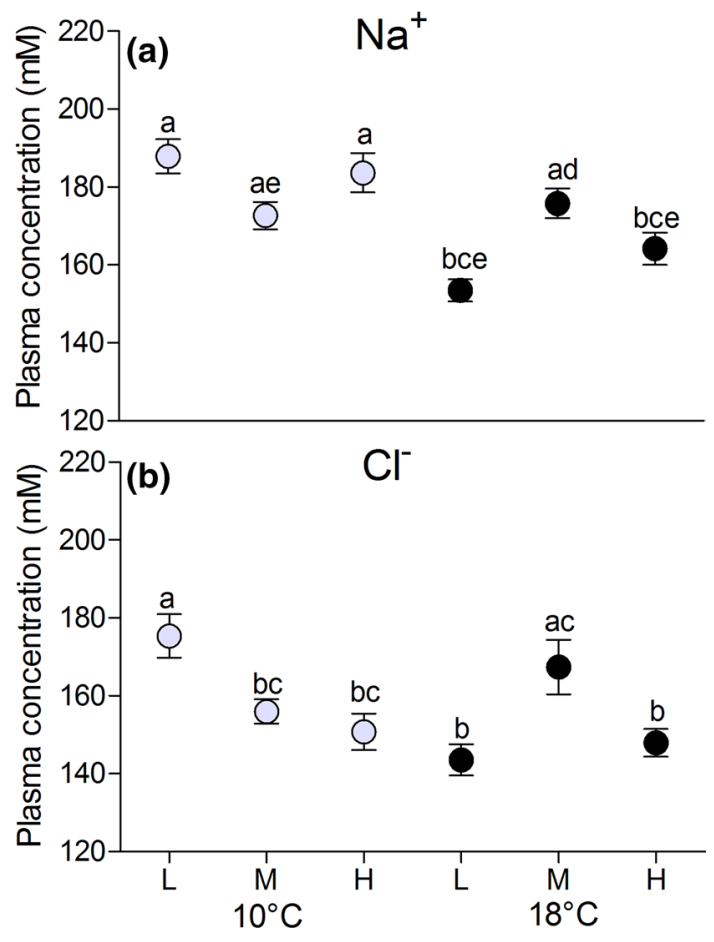

Fig. 3 a, b Blood plasma $\mathrm{Na}^{+}$and $\mathrm{Cl}^{-}$concentrations (mM) in plasma of cod 4 weeks exposed to low $P \mathrm{CO}_{2}=550 \mu$ atm (L), medium $P \mathrm{PC}_{2}=1200 \mu \mathrm{atm}(\mathrm{M})$ and high $P \mathrm{PO}_{2}=2200 \mu \mathrm{atm}(\mathrm{H})$ at $10{ }^{\circ} \mathrm{C}$ (grey circles) and at $18{ }^{\circ} \mathrm{C}$ (black circles). $n=18-20$ per treatment. Different letters indicate significant differences between treatment groups $(p<0.05)$

Warming to $18{ }^{\circ} \mathrm{C}$ under low $\mathrm{PCO}_{2}$ led to a $\sim 20 \%$ reduction in the concentrations of both ions $(p=0.012$, Fig. 3a, b). At $18{ }^{\circ} \mathrm{C}$ and medium $\mathrm{PCO}_{2}, \mathrm{Na}^{+}$and $\mathrm{Cl}^{-}$concentrations were less distinct from the group at $10{ }^{\circ} \mathrm{C}$ and low $\mathrm{PCO}_{2}$. This pattern was not observed at high $\mathrm{PCO}_{2}$ and $18{ }^{\circ} \mathrm{C}$ such that plasma ion levels at $18{ }^{\circ} \mathrm{C}$ were reduced in fish under low and high $\mathrm{CO}_{2}$ levels compared to medium $P \mathrm{CO}_{2}\left(\mathrm{Na}^{+}\right.$: low $P \mathrm{PO}_{2} p=0.002$, high $P \mathrm{CO}_{2} p=0.004$; $\mathrm{Cl}^{-}$: low $P \mathrm{CO}_{2} p=0.002$, high $P \mathrm{CO}_{2} p=0.006$ ) (Fig. 3a, b). For animals from all treatments, mean plasma $\mathrm{Na}^{+}$ concentration exceeded that of $\mathrm{Cl}^{-}$by $14-31 \mathrm{mM}$ positive charges. Plasma bicarbonate for the high $\mathrm{PCO}_{2}$ group at $18^{\circ} \mathrm{C}$ was in the range of $9.81 \pm 1.68 \mathrm{mM}$.

\section{Gill fresh weight}

Mean gill fresh weight determined per single arch after gill respiration experiments was $\mathrm{CO}_{2}$ dependent at $10^{\circ} \mathrm{C}$. Soft gill tissue and thereby also total gill weight increased in fish at $10^{\circ} \mathrm{C}$ and medium or high $\mathrm{PCO}_{2}(p<0.05)$ compared to the group at $10{ }^{\circ} \mathrm{C}$ and low $\mathrm{PCO}_{2}$ (Table 5). This pattern was also mirrored in the fraction of gill soft tissue weight (related to whole animal weight) and thereby independent of an allometric effect 
Table 5 Weight of total gill, respectively, gill soft tissue without cartilaginous arch, as well as fractional soft tissue weight related to whole animal weight of the differently exposed groups (low $\mathrm{PCO}_{2}=550 \mu \mathrm{atm}$; medium $P \mathrm{CO}_{2}=1200 \mu \mathrm{atm}$ and high $\mathrm{PCO}_{2}=2200 \mu$ atm at $10{ }^{\circ} \mathrm{C}$; $18{ }^{\circ} \mathrm{C}$ ) given as mean \pm standard deviation, $n=40$ per treatment for total gill and soft tissue weight, $n=3-8$ for fractional (\%) gill weight

\begin{tabular}{lllllll}
\hline weight $(\mathrm{g})$ & $10{ }^{\circ} \mathrm{C}$ low & $10^{\circ} \mathrm{C}$ medium & $10^{\circ} \mathrm{C}$ high & $18{ }^{\circ} \mathrm{C}$ low & $18{ }^{\circ} \mathrm{C}$ medium & $18{ }^{\circ} \mathrm{C}$ high \\
\hline Gill arch & $0.52 \pm 0.15 \mathrm{a}$ & $0.65 \pm 0.25 \mathrm{bc}$ & $0.69 \pm 0.25 \mathrm{~b}$ & $0.56 \pm 0.25 \mathrm{ac}$ & $0.57 \pm 0.21 \mathrm{ac}$ & $0.52 \pm 0.20 \mathrm{a}$ \\
Gill soft tissue & $0.28 \pm 0.08 \mathrm{a}$ & $0.36 \pm 0.13 \mathrm{bc}$ & $0.38 \pm 0.15 \mathrm{~b}$ & $0.26 \pm 0.13 \mathrm{a}$ & $0.29 \pm 0.11 \mathrm{ac}$ & $0.26 \pm 0.12 \mathrm{a}$ \\
$\%$ Weight & $0.13 \pm 0.07 \mathrm{a}$ & $0.27 \pm 0.22 \mathrm{~b}$ & $0.18 \pm 0.11 \mathrm{bc}$ & $0.17 \pm 0.14 \mathrm{ab}$ & $0.12 \pm 0.04 \mathrm{a}$ & $0.16 \pm 0.10 \mathrm{ab}$ \\
\hline
\end{tabular}

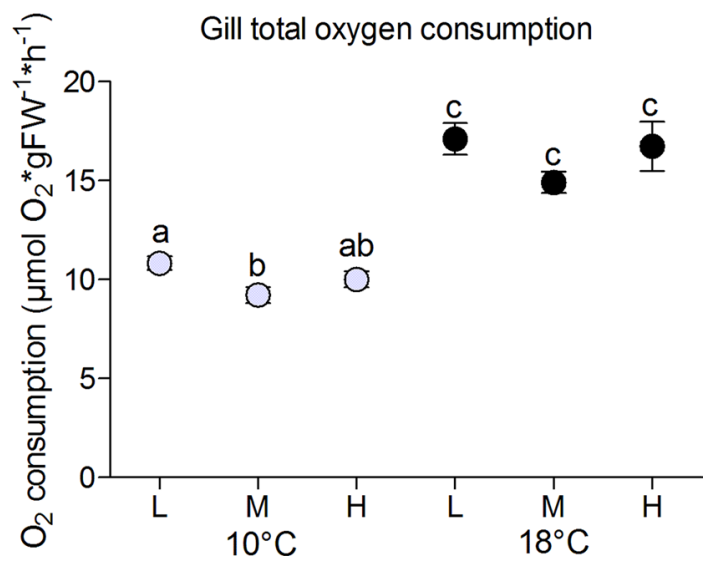

Fig. 4 Gill total oxygen consumption $\left(\mu \mathrm{mol} \mathrm{O}_{2} \times \mathrm{gFW}^{-1} \times \mathrm{h}^{-1}\right)$ of cod 4 weeks exposed to low $P \mathrm{PO}_{2}=550 \mu \mathrm{atm}(\mathrm{L})$, medium $\mathrm{PCO}_{2}=1200 \mu \mathrm{atm}(\mathrm{M})$ and high $\mathrm{PCO}_{2}=2200 \mu \mathrm{atm}(\mathrm{H})$ at $10{ }^{\circ} \mathrm{C}$ (grey circles) and at $18{ }^{\circ} \mathrm{C}$ (black circles). $n=40$ per treatment. Different letters indicate significant differences between treatment groups $(p<0.05)$

(Table 5). At high temperature, no $\mathrm{CO}_{2}$ effect was observed. Weights of total gill and gill soft tissue for the three groups at $18^{\circ} \mathrm{C}$ were in the range of those from low $\mathrm{PCO}_{2}$ fish at $10^{\circ} \mathrm{C}$, being significantly lower than the size-increased gills in fish at $10{ }^{\circ} \mathrm{C}$ and medium or high $\mathrm{PCO}_{2}$ treatments.

\section{Gill respiration and energy budget of ion regulation transporters}

Mean oxygen consumption related to gill soft tissue was $10.8 \mu \mathrm{mol} \mathrm{O}_{2} \times \mathrm{gFW}^{-1} \times \mathrm{h}^{-1}$ at $10{ }^{\circ} \mathrm{C}$ and low $\mathrm{PCO}_{2}$, whereas gills from fish reared at $10{ }^{\circ} \mathrm{C}$ and medium $\mathrm{PCO}_{2}$ displayed respiration rates about $15 \%$ lower than those at low $\mathrm{PCO}_{2}$ ( $p=0.013$ ) (Fig. 4). Gill oxygen consumption rates at high $\mathrm{PCO}_{2}$ and $10{ }^{\circ} \mathrm{C}$ were found between those at the other $\mathrm{PCO}_{2}$ levels, but did not differ significantly from those. Fish acclimated to $18{ }^{\circ} \mathrm{C}$ had higher branchial respiration rates than those reared at $10^{\circ} \mathrm{C}(p<0.001)$ (Fig. 4), following a $Q_{10}$ of $1.8 \pm 0.07$. Gill oxygen consumption rates at the three $\mathrm{PCO}_{2}$ levels and $18{ }^{\circ} \mathrm{C}$ were not statistically different. Again, respiration rates were lowest at medium $\mathrm{PCO}_{2}$ as observed before at $10{ }^{\circ} \mathrm{C}(p=0.057$, Fig. 4).

Net $\mathrm{O}_{2}$ demand of ion transporters, calculated as the difference between respiration rates of untreated and inhibitor-exposed gills, is presented in Fig. 6a-d; fractional costs in percent of total gill respiration are listed in Table 6. The inhibition of $\mathrm{Na}^{+} / \mathrm{H}^{+}$-exchanger (EIPA) and $\mathrm{HCO}_{3}{ }^{-}$-transporter (DIDS) occasionally led to respiration rates above controls, especially at medium $\mathrm{PCO}_{2}$ and $10{ }^{\circ} \mathrm{C}$, indicating a compensatory increase in the activity of other transporters (Fig. 5c, d). For the transporters investigated, the largest fraction of branchial energy was claimed by $\mathrm{Na}^{+} / \mathrm{K}^{+}$-ATPase, at $3.3 \pm 1.1$ and $5.4 \pm 1.7 \mu \mathrm{mol}$ $\mathrm{O}_{2} \times \mathrm{gFW}^{-1} \times \mathrm{h}^{-1}$ at 10 and $18{ }^{\circ} \mathrm{C}$, respectively (Fig. 5a), equivalent to $30 \%$ of total gill respiration at low $\mathrm{PCO}_{2}$ conditions. This fraction remained independent of temperature at medium $\mathrm{CO}_{2}$ concentrations, however, a significantly elevated $\mathrm{Na}^{+} / \mathrm{K}^{+}$-ATPase fraction (38.80\%) was observed at $18{ }^{\circ} \mathrm{C}$ and high $P \mathrm{CO}_{2}$, larger than at high $P \mathrm{CO}_{2}$ and $10{ }^{\circ} \mathrm{C}(21.5 \%)(p=0.022)$ (Table 6). Oxygen demand by $\mathrm{H}^{+}$-ATPase $\left(1.35 \pm 1.30 \mu \mathrm{mol} \mathrm{O} \mathrm{O}_{2} \times \mathrm{gFW}^{-1} \times \mathrm{h}^{-1}\right)$ and $\mathrm{Na}^{+} / \mathrm{H}^{+}$-exchanger $\left(1.36 \pm 1.21 \mu \mathrm{mol} \mathrm{O}{ }_{2} \times \mathrm{gFW}^{-1} \times \mathrm{h}^{-1}\right)$

Table 6 Cod gill fractional costs $(\%)$ of $\mathrm{Na}^{+} / \mathrm{K}^{+}$-ATPase, $\mathrm{H}^{+}$-ATPase, $\mathrm{HCO}_{3}{ }^{-}$-transporter and $\mathrm{Na}^{+} / \mathrm{H}^{+}$-exchanger in the different exposed groups (low $\mathrm{PCO}_{2}=550 \mu \mathrm{atm}$; medium $\mathrm{PCO}_{2}=1200 \mu \mathrm{atm}$ and high $P \mathrm{PO}_{2}=2200 \mu \mathrm{atm}$ at $10^{\circ} \mathrm{C} ; 18^{\circ} \mathrm{C}$ ) given as mean \pm standard deviation

\begin{tabular}{lcccccc}
\hline$\%$ & $10{ }^{\circ} \mathrm{C}$ low & $10{ }^{\circ} \mathrm{C}$ medium & $10{ }^{\circ} \mathrm{C}$ high & $18{ }^{\circ} \mathrm{C}$ low & $18{ }^{\circ} \mathrm{C}$ medium & $18{ }^{\circ} \mathrm{C}$ high \\
\hline $\mathrm{Na}^{+} / \mathrm{K}^{+}$-ATPase & $29.95 \pm 5.64 \mathrm{ab}$ & $28.60 \pm 10.99 \mathrm{ab}$ & $21.53 \pm 18.77 \mathrm{~b}$ & $29.95 \pm 8.53 \mathrm{ab}$ & $30.65 \pm 14.83 \mathrm{ab}$ & $38.8 \pm 11.04 \mathrm{ac}$ \\
$\mathrm{H}^{+}$-ATPase & $10.37 \pm 10.45$ & $6.23 \pm 21.89$ & $8.70 \pm 7.66$ & $14.81 \pm 8.84$ & $11.25 \pm 19.16$ & $11.18 \pm 9.21$ \\
$\mathrm{HCO}_{3}{ }^{-}$-transporter & $3.68 \pm 12.84 \mathrm{ab}$ & $1.79 \pm 20.81 \mathrm{ab}$ & $11.33 \pm 17.59 \mathrm{ab}$ & $4.93 \pm 10.47 \mathrm{ac}$ & $3.59 \pm 11.25 \mathrm{ad}$ & $23.57 \pm 12.21 \mathrm{~b}$ \\
$\mathrm{Na}^{+} / \mathrm{H}^{+}$-exchanger & $11.37 \pm 9.59 \mathrm{ab}$ & $-3.48 \pm 17.06 \mathrm{ab}$ & $10.64 \pm 7.80 \mathrm{ab}$ & $3.67 \pm 12.43 \mathrm{ac}$ & $7.47 \pm 14.19 \mathrm{ad}$ & $19.28 \pm 8.46 \mathrm{~b}$ \\
\hline
\end{tabular}

Different letters indicate significant differences in fractional costs of processes between treatments $(p<0.05), n=8$ per treatment 


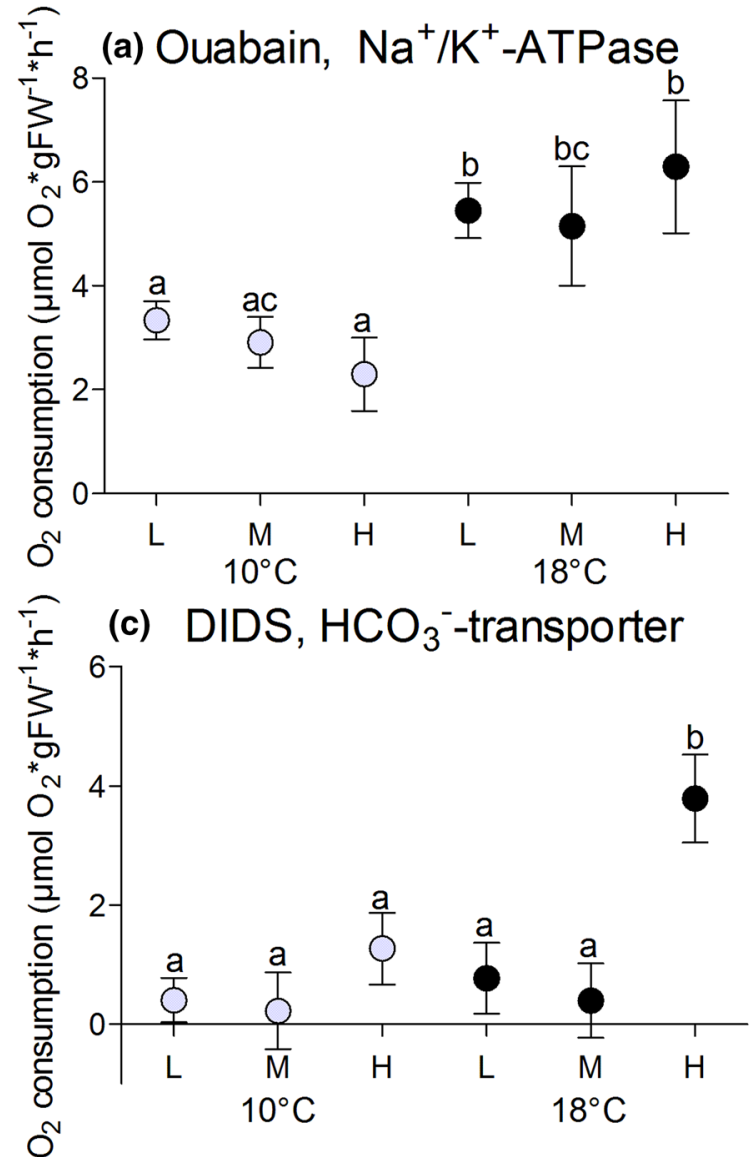

Fig. 5 a-d Net $\mathrm{O}_{2}$ demand of cod gill $\mathrm{Na}^{+} / \mathrm{K}^{+}$-ATPase (a), $\mathrm{H}^{+}$ATPase (b), $\mathrm{HCO}_{3}{ }^{-}$-transporter (c) and $\mathrm{Na}^{+} / \mathrm{H}^{+}$-exchanger $(\mathbf{d})(\mu \mathrm{mol}$ $\mathrm{O}_{2} \times \mathrm{gFW}^{-1} \times \mathrm{h}^{-1}$ ) of cod 4 weeks exposed to low $\mathrm{PCO}_{2}=550$

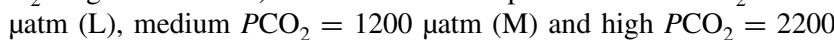

at low $\mathrm{PCO}_{2}$ and $10{ }^{\circ} \mathrm{C}$ both comprised about $11 \%$ of total gill respiration. $\mathrm{HCO}_{3}{ }^{-}$-transporter consumed about $3.7 \pm 12.8 \%\left(0.4 \pm 1.2 \mu \mathrm{mol} \mathrm{O}_{2} \times \mathrm{gFW}^{-1} \times \mathrm{h}^{-1}\right)$ (Fig. 5b-d; Table 6). At $18{ }^{\circ} \mathrm{C}$, net $\mathrm{O}_{2}$ demand of $\mathrm{Na}^{+} /$ $\mathrm{K}^{+}$-ATPase was elevated above rates seen in gills at $10^{\circ} \mathrm{C}$ $(p<0.05)$, except when comparing the two medium $\mathrm{PCO}_{2}$ treatments which differed less $(p=0.098) . \mathrm{O}_{2}$-demand of $\mathrm{H}^{+}$-ATPase was also elevated at high temperature, but this effect became statistically significant only between gills at high $\mathrm{PCO}_{2}$ and $10{ }^{\circ} \mathrm{C}$ and those at low $\mathrm{PCO}_{2}$ and $18{ }^{\circ} \mathrm{C}(p=0.023) . \mathrm{CO}_{2}$ dependent shifts in the usage of ion transporters were observed for $\mathrm{Na}^{+} / \mathrm{H}^{+}$-exchanger at both temperatures and for $\mathrm{HCO}_{3}{ }^{-}$transport at $18{ }^{\circ} \mathrm{C}$. $\mathrm{Na}^{+}$/ $\mathrm{H}^{+}$-exchanger was reduced in terms of oxygen demand at medium $\mathrm{PCO}_{2}$ and $10{ }^{\circ} \mathrm{C}$ below rates at low $\mathrm{PCO}_{2}$ $(p=0.017)$ and rose at high $P \mathrm{CO}_{2}$ and $18{ }^{\circ} \mathrm{C}$ compared to gills of all other treatments $\left(18{ }^{\circ} \mathrm{C}\right.$ low $P^{\circ} \mathrm{CO}_{2}$ 7.6-fold, $p=0.017 ; 18{ }^{\circ} \mathrm{C}$ medium $P_{2} \mathrm{CO}_{2} 2.6$-fold, $p=0.025$; $10{ }^{\circ} \mathrm{C}$ low $\mathrm{PCO}_{2} 2.3$-fold, $p=0.016 ; 10{ }^{\circ} \mathrm{C}$ medium $\mathrm{PCO}_{2}$
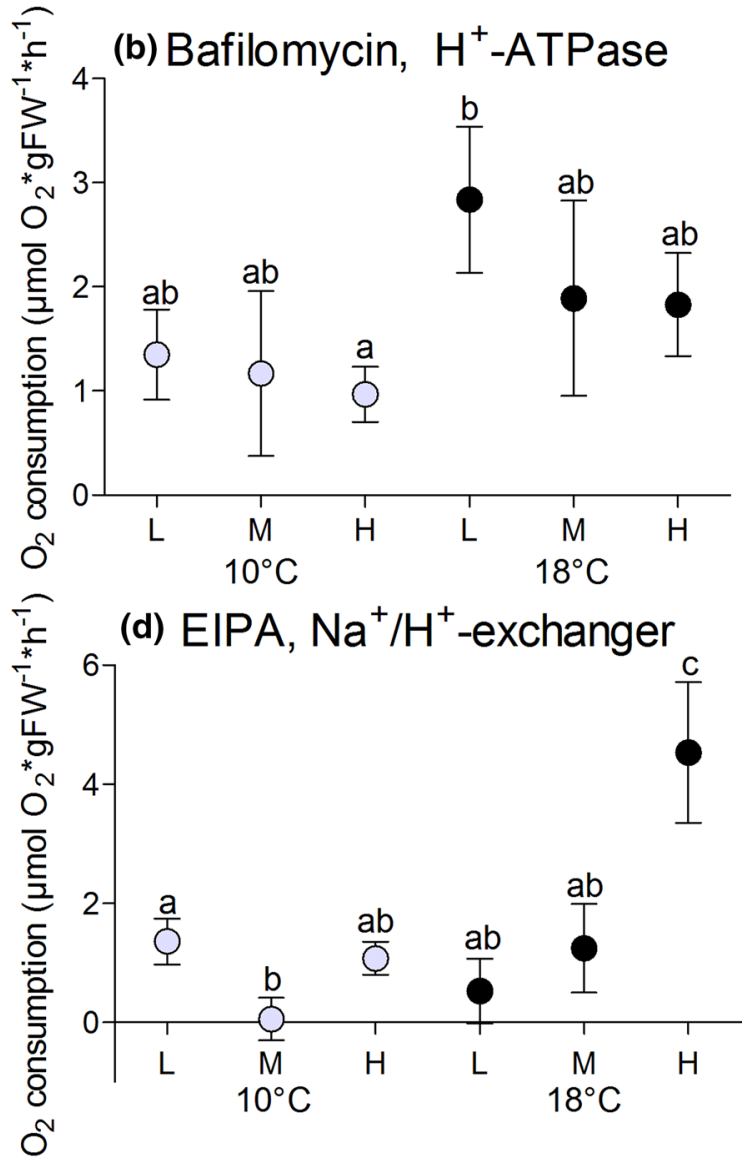

$\mu$ atm $(\mathrm{H})$ at $10{ }^{\circ} \mathrm{C}$ (grey circles) and at $18{ }^{\circ} \mathrm{C}$ (black circles), given as means with standard error of the mean. Letters indicate significant differences in net $\mathrm{O}_{2}$ demand of processes between treatment groups $(p<0.05), n=10$ per treatment

82.8 -fold $p=0.001,10{ }^{\circ} \mathrm{C}$ high $P \mathrm{CO}_{2} 4.2$-fold, $p=0.008$ ). Mean absolute oxygen demand of $\mathrm{HCO}_{3}{ }^{-}$transport was eightfold higher at high $\mathrm{PCO}_{2}$ and $18{ }^{\circ} \mathrm{C}$ than at medium $\mathrm{PCO}_{2}$ and $18{ }^{\circ} \mathrm{C}(p=0.002)$ and at low $\mathrm{PCO}_{2}$ conditions and $10{ }^{\circ} \mathrm{C}(p=0.0006)$, whereas oxygen demand of $\mathrm{HCO}_{3}{ }^{-}$transport was increased fourfold at high $\mathrm{PCO}_{2}$ and $18{ }^{\circ} \mathrm{C}$ compared to low $\mathrm{PCO}_{2}$ gills at $18{ }^{\circ} \mathrm{C}(p=0.007)$ (Fig. 5c).

In gills at $18{ }^{\circ} \mathrm{C}$ compared to those at $10{ }^{\circ} \mathrm{C}$ and the same level of $P \mathrm{CO}_{2}$ warming led to a strong $\mathrm{PCO}_{2}$ effect as indicated by elevated net $\mathrm{O}_{2}$ demand and an increase in the respective $Q_{10}$ values (Fig. 5a-d; Table 7). Three of the four transporters investigated had a significantly higher net $\mathrm{O}_{2}$-demand at high $\mathrm{PCO}_{2}: \mathrm{Na}^{+} / \mathrm{K}^{+}$-ATPase, $(p=0.013)$, $\mathrm{Na}^{+} / \mathrm{H}^{+}$-exchanger, $(p=0.008), \mathrm{HCO}_{3}{ }^{-}$-transporter, $(p=0.016)$. The related $Q_{10}$ values for transporter activity between 10 and $18{ }^{\circ} \mathrm{C}$ under high $P \mathrm{PO}_{2}$ ranged between 2.6 and 5.8 (Table 7). 
Table $7 Q_{10}$ values calculated for the mean net oxygen demand of the four transporters investigated between 10 and $18{ }^{\circ} \mathrm{C}$ groups at the respective $\mathrm{PCO}_{2}$ levels

\begin{tabular}{llcl}
\hline$Q_{10}$ & Low $P C O_{2}$ & Medium $P C O_{2}$ & High $P C C_{2}$ \\
\hline $\mathrm{Na}^{+} / \mathrm{K}^{+}$-ATPase & 1.78 & 2.05 & 3.78 \\
$\mathrm{H}^{+}$-ATPase & 1.93 & 1.80 & 2.58 \\
$\mathrm{HCO}_{3}{ }^{-}$-transporter & 0.88 & 0.65 & 3.18 \\
$\mathrm{Na}^{+} / \mathrm{H}^{+}$-exchanger & 0.32 & 29.68 & 5.81 \\
\hline
\end{tabular}

(a) Fractional gill soft tissue weight

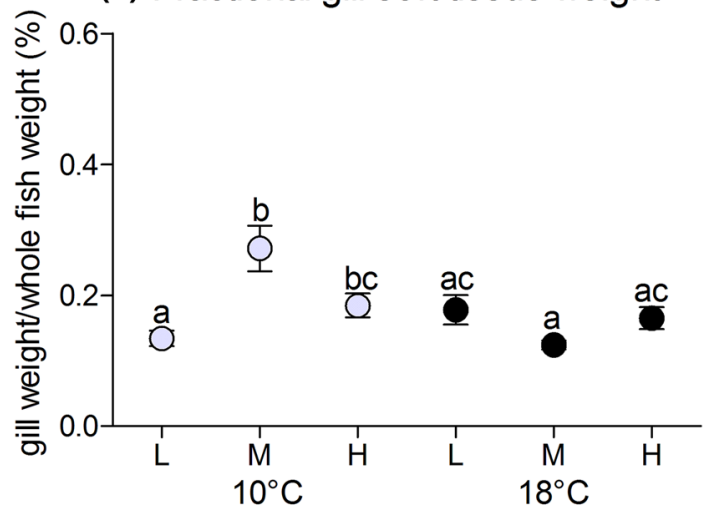

(b) Fractional gill soft tissue $\mathrm{MO}_{2}$

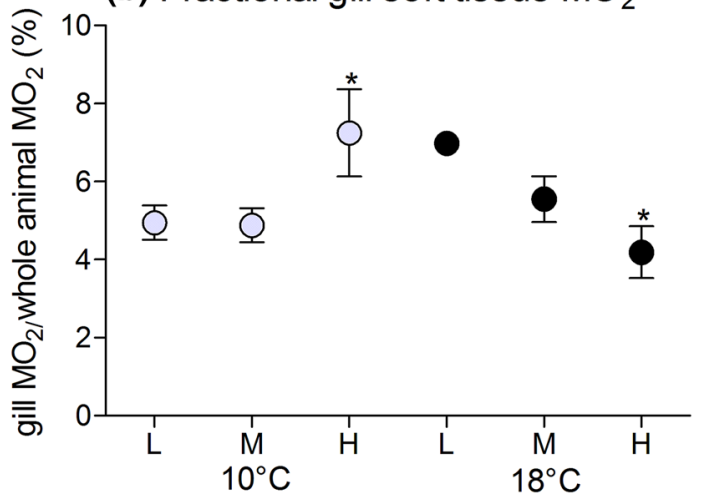

Fig. 6 a, b Gill total respiration (a) and weight (b) as the fraction of standard metabolic rate, respectively, weight of whole animal 4 weeks exposed to low $P_{C O}=550 \mu$ atm $(\mathrm{L})$, medium $P_{C O}=1200 \mu \mathrm{atm}(\mathrm{M})$ and high $P \mathrm{PO}_{2}=2200 \mu \mathrm{atm}(\mathrm{H})$ at $10{ }^{\circ} \mathrm{C}$ (grey circles) and at $18{ }^{\circ} \mathrm{C}$ (black circles). $n=4-8$ per treatment, for $18{ }^{\circ} \mathrm{C}$ low $\mathrm{PCO}_{2}$ a mean relation was calculated. Letters indicate significant differences in net $\mathrm{O}_{2}$ demand of processes between treatment groups $(p<0.05)(\mathbf{a})$; symbols indicate significant differences between treatments (b) as not all groups could be tested against each other $(p<0.05)$

\section{Discussion}

Atlantic cod reared under various levels of $\mathrm{PCO}_{2}$ and temperature responded by adjustments in branchial ion regulation and associated costs with implications for whole animal oxygen demand, osmolality, and $\mathrm{Na}^{+}$and $\mathrm{Cl}^{-}$concentrations in the plasma.

\section{Whole animal respiration}

Standard metabolic rate (SMR) of cod (mean weight $193.34 \pm 62.4 \mathrm{~g})$ at $10^{\circ} \mathrm{C}$ and low $\mathrm{PCO}_{2}(2.3 \pm 0.6 \mu \mathrm{mol}$ $\mathrm{O}_{2} \times \mathrm{gFW}^{-1} \times \mathrm{h}^{-1}$ or $74.0 \pm 20.6 \mathrm{mg} \mathrm{O}_{2} \times \mathrm{kg}^{-1} \times \mathrm{h}^{-1}$ ) compare well with values published for $200 \mathrm{~g}$ Atlantic cod reared at $10^{\circ} \mathrm{C}$, ranging from $55-121 \mathrm{mg} \mathrm{O}_{2} \times \mathrm{kg}^{-1} \times \mathrm{h}^{-1}$ (Schurmann and Steffensen 1997). The potential impact of elevated $\mathrm{PCO}_{2}$ on aerobic scope and metabolic rates have been assessed in a number of fish species from the tropics to the Antarctic with the general hypothesis that the cost of coping with elevated $\mathrm{PCO}_{2}$ (acid-base and osmoregulation as well as cardiorespiratory adjustments) would increase SMR and/or cause a shift in energy budget and reduce aerobic scope and finally fitness (cf. Heuer and Grosell 2014). In Atlantic cod at $10{ }^{\circ} \mathrm{C}$, SMR remained unaffected by elevated ambient $P \mathrm{CO}_{2}$. At low $P \mathrm{PO}_{2}, \mathrm{SMR}$ was compensated for during long-term warm exposure leading to similar rates in 10 and $18{ }^{\circ} \mathrm{C}$ animals $(2.67 \pm 0.04 \mu \mathrm{mol}$ $\mathrm{O}_{2} \times \mathrm{h}^{-1} \times \mathrm{gFW}^{-1}$ or $85.38 \pm 1.3 \mathrm{mg} \mathrm{O}_{2} \times \mathrm{kg}^{-1} \times \mathrm{h}^{-1}$ ), similar to those in Atlantic cod from Øresund, near to our study location, after thermal acclimation for several months to 10 and $15{ }^{\circ} \mathrm{C}$ (Schurmann and Steffensen 1997). Such compensation for changing temperatures is in line with earlier findings that cod can undergo thermal acclimation and thereby endure warm periods. Despite the down-regulation of SMR during warm acclimation, branchial respiration rates were enhanced at $18{ }^{\circ} \mathrm{C}$ (all treatments) indicating a shift in energy budget (see above) possibly constraining residual aerobic scope (cf. Pörtner et al. 2010). Further careful analysis of various components of aerobic energy budget and their trade-offs under elevated $\mathrm{CO}_{2}$ levels is thus warranted. In line with a high capacity of warm acclimatisation, wild southern North Sea cod remained for several weeks in their natural habitat at temperatures above $16{ }^{\circ} \mathrm{C}$ (Righton et al. 2010). In contrast, Atlantic cod from Scotlands' west coast exposed to the same acclimation conditions as in the present study ( 10 and $18{ }^{\circ} \mathrm{C}$ for 4 weeks) displayed a $70 \%$ increase in routine metabolic rates during long-term warm exposure (Soofiani and Hawkins 1982), indicating that thermal acclimatisation capacity differs between cod populations (cf. Pörtner et al. 2008).

The response of SMR to increasing $P \mathrm{CO}_{2}$ levels was different at the two acclimation temperatures. While SMR at low $\mathrm{PCO}_{2}$ was similar due to effective compensation, SMR at $18^{\circ} \mathrm{C}$ under medium and high $\mathrm{PCO}_{2}$ was higher than in fish reared under the same $\mathrm{PCO}_{2}$ levels at $10{ }^{\circ} \mathrm{C}$ (Fig. 1). Elevated $\mathrm{PCO}_{2}$ may thus offset the compensation under warming and cause an increase in metabolic cost and/or capacity. Both warming and 
acidification occur regularly in summer in the cod's natural habitat with as yet unclear functional consequences.

\section{Gill maintenance costs}

Oxygen consumption rates of gills isolated from Kattegat/ Skagerrak cod reared at low $\mathrm{PCO}_{2}$ and $10{ }^{\circ} \mathrm{C}(5.81 \pm 1.19$ $\mu$ atm $\mathrm{O}_{2} \times \mathrm{gFW}^{-1} \times \mathrm{h}^{-1}$ ) (Fig. 1) were in the range found in previous studies (Lyndon 1994; Deigweiher et al. 2010), but $50 \%$ lower than those reported for Southern North Sea cod (Kreiss et al. 2015). Lower total gill oxygen demand might be attributed to seasonal changes or population differences.

Relating the weight and metabolic costs of soft gill tissue to the weight of the whole fish (Fig. 6a, b) revealed an interesting pattern. The fraction of soft gill tissue was significantly elevated in medium and high $\mathrm{PCO}_{2}$ fish at $10{ }^{\circ} \mathrm{C}$ compared to fish reared at low $P \mathrm{CO}_{2}$ and $10^{\circ} \mathrm{C}$ (twofold at medium $\mathrm{PCO}_{2}, 1.4$-fold at high $\mathrm{PCO}_{2} ; p<0.001$ ) (Fig. 6a). Such an increase in gill soft tissue mass in relation to whole animal weight may indicate branchial remodelling, a mechanism contributing to altered gill mass. Gill remodelling has also been reported in freshwater fish in response to various environmental factors (Goss et al. 1998; Nilsson 2007; Mitrovic and Perry 2009), and is supported by results from Atlantic halibut, where elevated $\mathrm{PCO}_{2}$ for 4 months caused an upregulation of proteins related to cellular turnover in the gill soft tissue (de Souza et al. 2014). A potentially higher total oxygen demand of larger gill arches will likely impact whole animal energy budget. Under low and medium $\mathrm{PCO}_{2}$ at $10{ }^{\circ} \mathrm{C}$ the fractional oxygen consumption of gills accounted for approx. $5 \%$ of whole animal oxygen demand at rest, while this fraction increased with falling whole animal rates at high $\mathrm{PCO}_{2}$ reaching $>7 \%(p=0.056)$ (Fig. 6b). For fish reared at $18{ }^{\circ} \mathrm{C}$ increasing $\mathrm{PCO}_{2}$ caused the fraction to decline with rising whole animal metabolic rates from about $7 \%$ at low $\mathrm{PCO}_{2}$ to $\sim 4 \%$ at high $P_{2}$. Taking into account that gill $\mathrm{MO}_{2}$ per gram soft tissue was maintained at high $\mathrm{PCO}_{2}$ and $10{ }^{\circ} \mathrm{C}$ (Fig. 4), we can postulate that branchial oxygen demand was increased due to the increase in tissue weight under this treatment (Fig. 6a) As gill oxygen consumption was stable in all $\mathrm{PCO}_{2}$ groups at $18{ }^{\circ} \mathrm{C}$ (Fig. 6a), higher demand for oxygen by other tissues would explain the reduced fractions of gill oxygen demand (Fig. 6b).

\section{Plasma osmolality and ion concentrations}

At $10{ }^{\circ} \mathrm{C}$, plasma osmolality was in the range of values reported earlier for cod and independent of ambient $\mathrm{CO}_{2}$ (Larsen et al. 1997; Herbert and Steffensen 2005). However, while osmolality remained constant at $10^{\circ} \mathrm{C}$, the concentration of $\mathrm{Cl}^{-}$was reduced in fish under $\mathrm{PCO}_{2} \geq 1200$ $\mu$ atm at $10{ }^{\circ} \mathrm{C}$. At this temperature, plasma $\mathrm{Na}^{+}$concentrations were only slightly reduced at medium $\mathrm{PCO}_{2}$ $(p=0.057)$ but not at high $\mathrm{PCO}_{2}$. This indicates that osmolality was balanced by other anions, and concomitantly raises the question which transport processes are responsible for the unequal reduction in $\mathrm{Na}^{+}$and $\mathrm{Cl}^{-}$plasma concentrations. Plasma bicarbonate levels, determined in fish at $10{ }^{\circ} \mathrm{C}$ and medium $\mathrm{PCO}_{2}$ compensated for the excess of positively charged $\mathrm{Na}^{+}$over $\mathrm{Cl}^{-}$up to a difference of $\sim 6 \mathrm{mM}$, supporting earlier findings that $\mathrm{HCO}_{3}{ }^{-} /$ $\mathrm{Cl}^{-}$exchange takes place under hypercapnia (Larsen et al. 1997).

Warming close to maximum summer temperatures $\left(18{ }^{\circ} \mathrm{C}\right)$ combined with hypercapnic conditions led to a different response in plasma osmolality and ion concentrations. All parameters showed non-linear "hump-backedcurves", with reduced ion concentrations and slightly lowered osmolality in animals at $18{ }^{\circ} \mathrm{C}$ under low and high $\mathrm{PCO}_{2}$, while plasma parameters of animals at medium $\mathrm{PCO}_{2}$ and $18{ }^{\circ} \mathrm{C}$ were significantly higher (Figs. 2, 5a, b). The shape of these curves remains unexplained, but medium $\mathrm{PCO}_{2}$ levels and $18{ }^{\circ} \mathrm{C}$ are frequently experienced by cod in warm summers and preadaptation to this conditions may exist.

The reduction of ion concentrations and the slightly lowered osmolality of fish at $18{ }^{\circ} \mathrm{C}$ and low and high $\mathrm{PCO}_{2}$ reflects altered gill ion transporter activities indicated by enhanced fractions in oxygen demand. Net $\mathrm{O}_{2}$ demand of $\mathrm{Na}^{+} / \mathrm{K}^{+}$-ATPase and less so of $\mathrm{H}^{+}$-ATPase increased in the warmth (Fig. 5a, b). Thermally uncompensated (i.e. stimulated) in vivo activities of $\mathrm{Na}^{+} / \mathrm{K}^{+}$-ATPase and increased maximum transporter capacities $\left(\mathrm{Na}^{+} / \mathrm{K}^{+}\right.$-ATPase and $\mathrm{H}^{+}$ATPase) were also observed in the former study (Kreiss et al. 2015) implying that $\mathrm{Na}^{+} / \mathrm{K}^{+}$-ATPase might overcompensate for enhanced branchial permeability in the warmth. Together with the slightly reduced osmolality caused by the loss in ion concentration $\left(\mathrm{Na}^{+}\right.$and $\left.\mathrm{Cl}^{-}\right)$in warm acclimated fish at low and at high $\mathrm{PCO}_{2}$ this indicates a shift in the electrochemical gradient with enhanced $\mathrm{NaCl}$ excretion against the inward ion gradient. Enhanced hypo-osmoregulation was reported before for Antarctic fish during warm acclimation (Gonzalez-Cabrera et al. 1995; Brauer et al. 2005). We assume that elevated transport capacities $\left(Q_{10}\right.$ effect) cause decreased osmolality despite higher leakage rates according to higher membrane fluidity. Thereby organic osmolytes may play a role in replacing inorganic osmolytes such as $\mathrm{Na}^{+}$and $\mathrm{Cl}^{-}$for the reasons mentioned above, but this compensation seems less effective for fish incubated at $18{ }^{\circ} \mathrm{C}$ under low and high $\mathrm{PCO}_{2}$ than observed in hypercapnic fish at $10{ }^{\circ} \mathrm{C}$.

As the altered plasma ion concentration does not match the observed usage of branchial ion transport for all treatment groups (see below), further ion regulatory organs, such as kidney and the gastrointestinal tract may be involved in $\mathrm{NaCl}$ absorption using the same transporter 
types as found in branchial epithelia $\left(\mathrm{Na}^{+} / \mathrm{K}^{+}\right.$-ATPase, $\mathrm{Na}^{+} / \mathrm{K}^{+} / 2 \mathrm{Cl}^{-}$cotransporter). Anion including $\mathrm{HCO}_{3}{ }^{-}$ exchange (e.g. $\mathrm{Cl}^{-}$and $\mathrm{Na}^{+}$dependent $\mathrm{HCO}_{3}{ }^{-}$exchanger) are also known to play an important role in the intestine and might cause altered plasma $\mathrm{Na}^{+}$and $\mathrm{Cl}^{-}$concentrations not explained by branchial processes (Marshall and Grosell 2005). For European flounder, reduced plasma osmolality was observed in response to experimentally enhanced intestinal bicarbonate excretion demonstrating that such alterations in the intestine can significantly impact whole animal osmolality status (Wilson et al. 2002).

\section{Gill ion regulation mechanisms in vivo}

The fractions of $\mathrm{Na}^{+} / \mathrm{K}^{+}$-ATPase, $\mathrm{H}^{+}$-ATPase, $\mathrm{Na}^{+} / \mathrm{H}^{+}$exchanger, and $\mathrm{HCO}_{3}{ }^{-}$-transporter in oxygen consumption comprise the activities of all isoforms of the respective transporter families. $\mathrm{Na}^{+} / \mathrm{K}^{+}$-ATPase (all isoforms) is located basolaterally (Evans et al. 2005). A basolateral location was also suggested for $\mathrm{H}^{+}$-ATPase in immunolocalization studies on dogfish (Squalus acanthias) and longhorn sculpin Myoxocephalus octodecimspinosus) (Tresguerres et al. 2005; Catches et al. 2006). Several isoforms were described for $\mathrm{Na}^{+} / \mathrm{H}^{+}$-exchange (e.g. Edwards et al. 2005; Deigweiher et al. 2008; Rimoldi et al. 2009) and $\mathrm{HCO}_{3}{ }^{-}$transport (e.g. Piermarini et al. 2002; Esbaugh et al. 2012) located either apically or basolaterally.

The isolated tissue model applied here provides first insight into the affected processes, and can be better related to the whole animal level than isolated and reconstituted membrane models. When discussing the results, the apical or basolateral localisation of transporters from the same family should be kept in mind. While the inhibitors applied may have side-effects on other transporters, this did probably not have a large influence on our findings as the observed patterns of the applied inhibitors are in line with a specific mode of action on certain transporter (families). Under all conditions, $\mathrm{O}_{2}$ demand of $\mathrm{Na}^{+} / \mathrm{K}^{+}$-ATPase comprised about $30 \%$ of total gill demand and thereby the largest fraction among the transporters investigated, followed by $\mathrm{H}^{+}$-ATPase and $\mathrm{Na}^{+} / \mathrm{H}^{+}$-exchanger (approx. $11 \%$ each) and $\mathrm{HCO}_{3}{ }^{-}$-transport (approx. $3 \%$ ). This is in line with fractions of $\mathrm{Na}^{+} / \mathrm{K}^{+}$-ATPase and $\mathrm{H}^{+}$-ATPase in oxygen demand of cutthroat trout gill, which accounted for $37 \%$ of total gill oxygen consumption (Morgan and Iwama 1999). Further studies examining fractions of oxygen allocation in isolated gills in vivo from marine fish found $\mathrm{Na}^{+} /$ $\mathrm{K}^{+}$-ATPase to represent between 11.8 and $23.1 \%$ of total gill respiration in two species of Notothenioidei (Deigweiher et al. 2010). The larger fractions of $43 \%$ in cod (Kreiss et al. 2015) might again be explained by seasonal variation, as observed for other fish species (e.g. in yellow perch Perca flavescens, Packer and Garvin 1998). Differences between populations might involve various ion transporter activities and thereby altered total gill oxygen demand as found between the two cod studies.

Long-term exposure under high $\mathrm{PCO}_{2}$ is known to affect gill ion regulation capacity in teleosts involving increased mRNA levels and protein abundance of basolateral $\mathrm{Na}^{+} /$ $\mathrm{HCO}_{3}{ }^{-}$cotransporter and $\mathrm{Na}^{+} / \mathrm{K}^{+}$-ATPase, while those of anion exchanger $\left(\mathrm{HCO}_{3}{ }^{-} / \mathrm{Cl}^{-}\right.$transporter $)$and $\mathrm{Na}^{+} / \mathrm{H}^{+}-$ exchanger remained at control levels (Zoarces viviparus, Deigweiher et al. 2008). In the present study, in vivo oxygen demand of these transporters at optimum temperature $\left(10{ }^{\circ} \mathrm{C}\right)$ indicates a different pattern: The summed oxygen demand elicited by $\mathrm{HCO}_{3}{ }^{-}$-transporters as well as $\mathrm{Na}^{+} / \mathrm{H}^{+}$exchangers indicates small responses to both hypercapnia levels applied. A slight enhancement of $\mathrm{HCO}_{3}{ }^{-}$-transporter activity occurred at high $\mathrm{PCO}_{2}$ level and the net $\mathrm{O}_{2}$ demand caused by $\mathrm{Na}^{+} / \mathrm{H}^{+}$-exchanger seen at the three $\mathrm{PCO}_{2}$ levels indicated minimum activity at medium but elevated activity under high $\mathrm{PCO}_{2}$ conditions. This indicates at least some involvement of both transporter types depending on the hypercapnia levels applied. Thereby, the interdependencies in the involvement of different transporters need to be considered, as in case of DIDS application to gills at $10{ }^{\circ} \mathrm{C}$. DIDS caused a stimulation of oxygen consumption, possibly due to a shift to other, more costly transporters, which compensated for inhibited $\mathrm{HCO}_{3}{ }^{-}$-transport. Such a response has been observed before in isolated tissue of a marine worm (Sipunculus nudus) (Pörtner et al. 2000).

Slightly decreased in vivo $\mathrm{Na}^{+} / \mathrm{K}^{+}$-ATPase activities at high $\mathrm{PCO}_{2}$, are in line with earlier observations (Melzner et al. 2009; Esbaugh et al. 2012; Kreiss et al. 2015), where under $P \mathrm{PO}_{2}$ levels $\leq 3000 \mu$ atm, branchial $\mathrm{Na}^{+} / \mathrm{K}^{+}$-ATPase capacities remained unchanged or were reduced, contrasting the upregulation observed under high $\mathrm{PCO}_{2} \geq 6000$ $\mu$ atm (Deigweiher et al. 2008, 2010; Melzner et al. 2009). The pathways eliciting these differences remain to be explored. $\mathrm{H}^{+}$-ATPase activity and its net $\mathrm{O}_{2}$ demand remained rather stable across $\mathrm{CO}_{2}$ treatments, indicating that the in vivo costs of proton excretion are not altered in the cod gill at optimum temperature after 4 weeks of exposure. In salmon, reduced levels of V-type $\mathrm{H}^{+}$-ATPase B-subunit mRNA were found under severe hypercapnia $(20,000 \mu \mathrm{atm}$, Seidelin et al. 2001), again a certain $\mathrm{PCO}_{2}$ threshold for the response may be postulated for the $\mathrm{H}^{+}$-ATPase. Downregulation of this basolateral pump may cause an increase in branchial $\mathrm{H}^{+}$-excretion. Taken together, no clear molecular restructuring in ion transport was observed after 4 weeks of acclimation to prospective $\mathrm{PCO}_{2}$ at optimum temperature.

However, gill remodelling and the increase in gill soft tissue under medium and high $\mathrm{PCO}_{2}$ at $10{ }^{\circ} \mathrm{C}$ (Fig. 6a; Table 5; also found in Kreiss et al. 2015) may affect ion transporter usage. Freshwater fish, exposed to acute severe 
hypercapnia $\left(\sim 2 \% \mathrm{CO}_{2}\right)$, displayed an increased branchial apical surface area of pavement cells, which reduced the surface area of exposed chloride cells and thereby modified the exchange rate of the apical $\mathrm{HCO}_{3}{ }^{-} / \mathrm{Cl}^{-}$exchanger (Goss et al. 1998). The authors concluded that this mechanism reduces base-excretion and thus compensated for acidosis. As pavement cells have a lower oxygen demand than chloride cells the relative increment of pavement cells may explain the increase in soft tissue at constant oxygen consumption rate per $\mathrm{g}$ gill arch under hypercapnia. Whether these changes occurred and affected the physical exposure of chloride cells and transporters involved, needs to be confirmed by histological and mechanistic analyses. The absence of increased branchial soft tissue mass in the warmth could be prevented by the otherwise counterproductive reduction of the respiratory surface area.

At $18{ }^{\circ} \mathrm{C}$ and elevated $\mathrm{PCO}_{2}, \mathrm{Na}^{+} / \mathrm{H}^{+}$-exchanger and $\mathrm{HCO}_{3}{ }^{-}$transporter both caused elevated $\mathrm{O}_{2}$ and energy demand compared to the respective rates at $10{ }^{\circ} \mathrm{C}$. $\mathrm{Na}^{+} /$ $\mathrm{H}^{+}$-exchanger elicited increased net $\mathrm{O}_{2}$ demand at both elevated $\mathrm{PCO}_{2}$ levels, whereas $\mathrm{HCO}_{3}{ }^{-}$-transport only did at high $\mathrm{PCO}_{2}$. Isoforms of $\mathrm{Na}^{+} / \mathrm{H}^{+}$-exchanger and $\mathrm{HCO}_{3}{ }^{-}$ transporter are localised either apically or basolaterally (cf. Heuer and Grosell 2014). Three isoforms of $\mathrm{Na}^{+} / \mathrm{H}^{+}$exchangers (NHEs) are involved in fish acid-base regulation, NHE1 on the basolateral and NHE2 and NHE3 on the apical side (Evans et al. 2005; Deigweiher et al. 2008). Various transporters are involved in $\mathrm{HCO}_{3}{ }^{-}$-transport and are blocked by DIDS; the most important in terms of acidbase regulation might be the apical and basolateral $\mathrm{HCO}_{3}{ }^{-} /$ $\mathrm{Cl}^{-}$exchangers, called anion exchanger (AEs) and a $\mathrm{Na}^{+}$/ $\mathrm{HCO}_{3}{ }^{-}$co-transporter on the basolateral side (NBC1). At $18{ }^{\circ} \mathrm{C}$, NHE costs were elevated in response to both hypercapnia treatments above those at low $\mathrm{PCO}_{2}$, indicating an upregulation of apical NHEs and enhanced acid excretion. In general, acid excretion in marine fish gills is thought to involve the thermodynamically favourable apical $\mathrm{Na}^{+}$/ $\mathrm{H}^{+}$-exchanger more than the costly $\mathrm{H}^{+}$-ATPase (Claiborne et al. 1999; Tresguerres et al. 2005). A predominant role for apical $\mathrm{Na}^{+} / \mathrm{H}^{+}$-exchange in acid-base regulation was also found in gills of fresh and seawater adapted mummichogs (Fundulus heteroclitus) under acute, more severe hypercapnia $(10,000 \mu \mathrm{atm})$ (Edwards et al. 2005), as well as during acid infusion (Claiborne et al. 1999). In this line, mRNA of the basolateral isoform of $\mathrm{Na}^{+} / \mathrm{H}^{+}$-exchanger was downregulated at least under short-term hypercapnia ( $1 \mathrm{~h}-4$ days; Deigweiher et al. 2008; Rimoldi et al. 2009). In the present study, in vivo costs of both $\mathrm{Na}^{+} / \mathrm{H}^{+}$-exchanger and $\mathrm{HCO}_{3}{ }^{-}$ transport were enhanced under high $\mathrm{CO}_{2}$ levels. This pattern might involve a higher usage and expression of $\mathrm{Na}^{+} /$ $\mathrm{HCO}_{3}{ }^{-}$-cotransporter $\mathrm{NBC} 1$ as observed before in gill tissues of eelpout (Zoarces viviparus) acclimated for 6 weeks to $10,000 \mu$ atm $\mathrm{CO}_{2}$ (Deigweiher et al. 2008).
Independent of the particular mechanism, our data support that either $\mathrm{Na}^{+} / \mathrm{HCO}_{3}{ }^{-}$-cotransporter or $\mathrm{HCO}_{3}{ }^{-}$/ $\mathrm{Cl}^{-}$-exchanger, in parallel to $\mathrm{Na}^{+} / \mathrm{H}^{+}$-exchanger play a dominant role in cod acid-base regulation under moderate hypercapnia in the warmth. The observed stimulation of ion transporters at elevated $\mathrm{PCO}_{2}$ and $18{ }^{\circ} \mathrm{C}$ did not result in alterations of total gill oxygen consumption rates compared to low $\mathrm{PCO}_{2}$ at $18{ }^{\circ} \mathrm{C}$. Stable total gill oxygen consumption despite shifted usage of ion transporter was observed before in Antarctic fish at 10,000 $\mu \mathrm{atm} \mathrm{CO}_{2}$ (Deigweiher et al. 2010). The mechanistic background of this stability remains to be explored.

\section{Conclusions and perspectives}

Whole animal standard metabolic rates of Atlantic cod incubated for 3 weeks were independent of temperature (10, $\left.18{ }^{\circ} \mathrm{C}\right)$. These results confirm previous findings that Southern cod populations can acclimate and compensate for temperature, within limits marginally reached at $18{ }^{\circ} \mathrm{C}$. With respect to the different $\mathrm{CO}_{2}$ concentrations applied (550, 1200 and $2200 \mu \mathrm{atm})$, these data also provide an evidence that near-term projected future $\mathrm{PCO}_{2}$ levels per se will have a small effect on SMR. Due to the changes in whole animal SMR between medium and high $\mathrm{PCO}_{2}$ groups of the two temperatures studied, we observed increasing fractions of gill in whole organism oxygen demand towards high $\mathrm{PCO}_{2}$ at $10^{\circ} \mathrm{C}$ but decreasing fractions under rising $P \mathrm{CO}_{2}$ at $18{ }^{\circ} \mathrm{C}$. This reflects increased overall gill oxygen consumption at $10{ }^{\circ} \mathrm{C}$ and high $\mathrm{PCO}_{2}$, whereas gills in fish at $18{ }^{\circ} \mathrm{C}$ displayed rather stable branchial oxygen demand that was not involved in fluctuations of cod energy turnover under $\mathrm{CO}_{2}$.

In parallel, our data provide evidence of increased demand for branchial ion regulation through $\mathrm{Na}^{+} / \mathrm{H}^{+}$exchange and $\mathrm{HCO}_{3}{ }^{-}$-transport at $18{ }^{\circ} \mathrm{C}$ and elevated $\mathrm{PCO}_{2}$ leading to an associated reduction in inorganic plasma osmolytes via stimulated $\mathrm{Na}^{+} / \mathrm{K}^{+}$-ATPase and a shift in plasma ionic balance; the latter effect was also observed at low $\mathrm{PCO}_{2}$ and $18{ }^{\circ} \mathrm{C}$. Reduced net $\mathrm{O}_{2}$ demand of $\mathrm{Na}^{+} / \mathrm{H}^{+}$-exchanger under medium $P \mathrm{PO}_{2}$ as well as the slight decrease of net $\mathrm{Na}^{+} / \mathrm{K}^{+}$-ATPase $\mathrm{O}_{2}$ demand under high $\mathrm{PCO}_{2}$ at $10{ }^{\circ} \mathrm{C}$ is an evidence for a different mechanism at optimum temperature than at $18{ }^{\circ} \mathrm{C}$. To what extent these changes contribute to shifts in somatic energy turnover and budget, remains to be explored. Overall, Atlantic cod appear quite tolerant to elevated $\mathrm{CO}_{2}$ levels and variable temperatures, which may come with its demersal lifestyle and preadaptations to fluctuating $\mathrm{CO}_{2}$ levels and fluctuating temperatures in shallow water habitats.

Acknowledgments The authors would like to thank Bengt Lundve for his support and assistance in obtaining experimental animals 
and arranging the experimental facilities as well as Lars Ljungqvist for valuable technical support. Lena Jakob and Caroline Otten are highly acknowledged for their assistance in plasma ion analysis. Furthermore, we would like to thank the constructive criticism by two anonymous reviewers which greatly improved the manuscript. This work contributes to the Bundesministerium für Forschung und Bildung funded project "Biological Impacts of Ocean Acidification" (BIOACID) and is part of the "Polar regions and coasts in a changing earth system" (PACES) research programme of the Alfred-WegenerInstitute for Polar and Marine Research.

Open Access This article is distributed under the terms of the Creative Commons Attribution 4.0 International License (http://creativecommons.org/licenses/by/4.0/), which permits unrestricted use, distribution, and reproduction in any medium, provided you give appropriate credit to the original author(s) and the source, provide a link to the Creative Commons license, and indicate if changes were made.

\section{References}

Blackford JC, Gilbert FJ (2007) pH variability and $\mathrm{CO}_{2}$ induced acidification in the North Sea. J Marine Syst 64:229-241

Brauer PR, Sanmann JN, Petzel DH (2005) Effects of warm acclimation on $\mathrm{Na}^{+}, \mathrm{K}^{+}$-ATPase $\alpha$-subunit expression in chloride cells of Antarctic fish. Anat Rec A 285A:600-609

Butler PJ, Axelsson M, Ehrenström F, Metcalfe JD, Nilsson S (1989) Circulating catecholamines and swimming performance in the Atlantic cod, Gadus morhua. J Exp Biol 141:377-387

Catches JS, Burns JM, Edwards SL, Claiborne JB (2006) $\mathrm{Na}^{+} / \mathrm{H}^{+}$ antiporter, $\mathrm{V}-\mathrm{H}^{+}$-ATPase and $\mathrm{Na}^{+} / \mathrm{K}^{+}$-ATPase immunolocalization in a marine teleost (Myoxocephalus octodecemspinosus). $\mathrm{J}$ Exp Biol 204:3251-3259

Claiborne JB, Blackston CR, Choe KP, Dawson DC, Harris SP, Mackenzie LA, Morrison-Shetlar AI (1999) A mechanism for branchial acid excretion in marine fish: identification of multiple $\mathrm{Na}^{+} / \mathrm{H}^{+}$antiporter (NHE) isoforms in gills of two seawater fish. J Exp Biol 202:315-324

Claiborne JB, Edwards SL, Morrison-Shetlar AI (2002) Acid-Base Regulation in Fishes: cellular and Molecular Mechanisms. J Exp Biol 293:302-319

Collins M, Knutti R, Arblaster J, Dufresne JL, Fichefet T, Friedlingstein P, Gao X, Gutowski WJ, Johns T, Krinner G, Shongwe M, Tebaldi C, Weaver AJ, Wehner M (2013) The Physical Science Basis. Contribution of Working Group I to the Fifth Assessment Report of the Intergovernmental Panel of Climate Change Stocker TF, Qin D, Plattner GK, Tignor M, Allen SK, Boschung J, Nauels A, Xia Y, Bex V, Midgley PM (eds.). Cambridge University Press, Cambridge, United Kingdom and New York, NY, USA

De Souza KB, Jutfelt F, Kling P, Förlin L, Sturve J (2014) Effects of increased $\mathrm{CO}_{2}$ on fish gill and plasma proteome. PLoS One 9(7):e102901. doi:10.1371/journal.pone.0102901

Deigweiher K, Koschnick N, Pörtner HO, Lucassen M (2008) Acclimation of ion regulatory capacities in gills of marine fish under environmental hypercapnia. Am J Physiol Regul Integr Comp Physiol 295:R1660-R1670

Deigweiher K, Hirse T, Bock C, Lucassen M, Pörtner HO (2010) Hypercapnia induced shifts in gill energy budgets of Antarctic notothenioids. J Comp Physiol 180B:347-359

Dickson AG, Millero FJ (1987) A comparison of the equilibrium constants for the dissociation of carbonic acid in seawater media. Deep-Sea Res 34:1733-1743

Drinkwater KF (2005) The response of Atlantic cod (Gadus morhua) to future climate change. ICES J Mar Sci 62:1327-1337
Duraton C, Tauc M, Avella M, Poujeol P (1997) Chloride channels in primary cultures of seawater fish (Dicentrarchus labrax) gill. Cell Physiol 273:C874-C882

Edwards SL, Wall BP, Morrison-Shetlar A, Sligh S, Weakley JC, Claiborne JB (2005) The effect of environmental hypercapnia and salinity on the expression of NHE-like isoforms in the gills of a euryhaline fish (Fundulus heteroclitus). J Exp Zool 303A(6):464-475

Esbaugh AJ, Heuer R, Grosell M (2012) Impacts of ocean acidification on respiratory gas exchange and acid-base balance in a marine teleost, Opsanus beta. J Comp Physiol 182B:921-934

Evans DH, Piermarini PM, Choe KP (2005) The multifunctional fish gill: dominant site of gas exchange, osmoregulation, acid-base regulation and excretion of nitrogenous waste. Physiol Rev 85:97-177

Forsgren E, Dupont S, Jutfelt F, Amundsen T (2013) Elevated $\mathrm{CO}_{2}$ affects embryonic development and larval phototaxis in a temperate marine fish. Ecol Evol 3(11):3637-3646

Frommel AY, Maneja R, Lowe D, Malzahn AM, Geffen AJ, Folkvord A, Piatkowski U, Reusch TBH, Clemmesen C (2011) Severe tissue damage in Atlantic cod larvae under increasing ocean acidification. Nat Clim Chang. doi:10.1038/NCLIMATE1324

Frommel AY, Schubert A, Piatkowski U, Clemmesen C (2013) Egg and early larval stages of Baltic cod, Gadus morhua, are robust to high levels of ocean acidification. Mar Biol 160:1825-1834

Gonzalez-Cabrera PJ, Dowd F, Pedibhotla VK, Rosario R, StanleySamuelson D, Petzel D (1995) Enhanced hypo-osmoregulation induced by warm-acclimation in Antarctic fish is mediated by increased gill and kidney $\mathrm{Na}^{+} / \mathrm{K}^{+}$-ATPase activities. J Exp Biol 198:2279-2291

Goss GG, Perry SF, Fryer JN, Laurent P (1998) Gill morphology and acid-base regulation in freshwater fishes. Comp Biochem Physiol 119A:107-115

Gypens N, Lacroix G, Lancelot C, Borges AV (2011) Seasonal and inter-annual variability of air-sea $\mathrm{CO}_{2}$ fluxes and seawater carbonate chemistry in the Southern North Sea. Prog Oceanogr 88:59-77

Heisler N (1984) Acid-base regulation in fishes. In: Hoar WS, Randall DJ (eds) Fish physiology, vol 10. Academic, New York, pp 315-401

Heisler N (1986) Buffering and transmembrane ion transfer processes. In: Heisler N (ed) Acid-base regulation in animals. Elsevier Biomedical Press, Amsterdam, pp 3-47

Herbert NA, Steffensen JF (2005) The response of Atlantic cod, Gadus morhua, to progressive hypoxia: fish swimming speed and physiological stress. Mar Biol 147:1403-1412

Heuer RM, Grosell M (2014) Physiological impacts of elevated carbon dioxide and ocean acidification on fish. Am J Physiol Regul Integr Comp Physiol 307:R1061-R1084

Holmgren S, Nilsson S (1974) Drug effects on Isolated Artery Strips from two teleosts, Gadus morhua and Salmo gairdneri. Act Physiol Scand 90:431-437

Jutfelt F, Hedgärde M (2013) Atlantic cod actively avoid $\mathrm{CO}_{2}$ and predator odour, even after long-term $\mathrm{CO}_{2}$ exposure. Front Zool 10:81

Kreiss CM, Michael K, Bock C, Lucassen M, Pörtner H-O (2015) Impact of long-term hypercapnia on the energy budget of isolated gills of Atlantic cod (Gadus morhua). Comp Biochem Physiol 182A:102-112

Krumschnabel G, Wieser W (1994) Inhibition of the sodium pump does not cause a stoichiometric decrease of ATP-production in energy limited fish hepatocytes. Experentia 50:483-485

Lannig G, Bock C, Sartoris F, Pörtner HO (2004) Oxygen limitation of thermal tolerance in cod, Gadus morhua L., studied by magnetic resonance imaging and online-venous oxygen monitoring. Am J Physiol Regul Integr Physiol Comp 287:R902-R910

Larsen BK, Pörtner HO, Jensen FB (1997) Extra- and intracellular acid-base balance and ionic regulation in cod (Gadus morhua) during combined and isolated exposures to hypercapnia and copper. Mar Biol 128:337-346 
Lebedeva NY, Vosilene MZY, Golovkina TV (1994) Aspects of stress in rainbow trout, Salmo gairdneri, release of chemical alarm signals. J Ichthyol 33:66-74

Lewis E, Wallace D (1998) Program developed for $\mathrm{CO}_{2}$ system calculations. In: ORNL/CDIAC-105a. Oak Ridge, Tenessee: Carbon Dioxide Information Analysis Center, Oak Ridge National Laboratory, U.S. Department of Energy

Lyndon AR (1994) A method for measuring oxygen consumption in isolated perfused gills. J Fish Biol 44(4):707-715

Maneja RH, Frommel AY, Browman HL, Clemmesen C, Geffen AJ, Folkvord A, Piatkowski U, Durif CMF, Bjelland R, Skiftesvik AB (2013) The swimming kinematics of larval Atlantic cod Gadus morhua L., are resilient to elevated seawater $p \mathrm{CO}_{2}$. Mar Biol 160:1963-1972

Mark FC, Hirse T, Pörtner HO (2005) Thermal sensitivity of cellular energy budgets in some Antarctic fish hepatocytes. Polar Biol 28:805-814

Marshall WS, Grosell M (2005) Ion transport, osmolytes and acid-base balance. In: Evans DH, Claiborne JB (eds) The physiology of fishes, 3rd edn. CRC Press Taylor and Francis Group, USA, pp 177-229

Mehrbach C, Culberson CH, Hawley JE, Pytkowicz RM (1973) Measurement of the apparent dissociation constants of carbonic acid in seawater at atmospheric pressure. Limnol Oceangr 18:897-907

Melzner F, Göbel S, Langenbuch M, Gutowska MA, Pörtner HO, Lucassen M (2009) Swimming performance in Atlantic Cod (Gadus morhua) following long-term (4-12 months) acclimation to elevated seawater $\mathrm{PCO}_{2}$. Aquat Toxicol 92:30-37

Mitrovic D, Perry SF (2009) The effects of thermally induced gill remodelling on ionocyte distribution and branchial chloride fluxes in goldfish (Carassius auratus). J Exp Biol 212:843-852

Morgan JD, Iwama GK (1999) Energy cost of NaCl transport in isolated gills of cutthroat trout. Am J Physiol Regul Integr Comp Physiol 277:R631-R639

Munday PL, McCormick MI, Nilsson E (2012) Impact of global warming and rising $\mathrm{CO}_{2}$ levels on coral reef fishes: what hope for the future? J Exp Biol 215:3865-3873

Neat F, Righton D (2007) Warm water occupancy by North Sea cod. Proc R Soc B. 274:789-798

Nilsson G (2007) Gill remodelling - a new fashion or an ancient secret? J Exp Biol 210:2403-2409

Nilsson GE, Dixson DL, Domenici P, McCormick MI, Sørensen C, Watson SW, Munday PL (2012) Near future carbon dioxide levels alter fish behaviour by interfering with neurotransmitter function. Nat Clim Chang. doi:10.1038/NCLIMATEE1352

Packer RK, Garvin JL (1998) Seasonal differences in activity of perch (Perca flavenscens) gill $\mathrm{Na}^{+} / \mathrm{K}^{+}$-ATPase. Comp Biochem Physiol 120B:777-783

Parks SK, Tresguerres M, Goss GG (2007) Interactions between $\mathrm{Na}^{+}$ channels and $\mathrm{Na}^{+}-\mathrm{HCO}^{-}$-cotransporters in the freshwater fish gill MR cell: a model for transepithelial $\mathrm{Na}^{+}$uptake. Am J Physiol Cell Physiol 292:935-944

Piermarini PM, Verlander JW, Royaux IE, Evans DH (2002) Pendrin immunoreactivity in the gill epithelium of a euryhaline elasmobranch. Am J Physiol Integr Comp Physiol 283:R983-R992

Pörtner HO, Knust R (2007) Climate change affects marine fishes through the oxygen limitation of thermal tolerance. Science 315:95

Pörtner HO, Peck MA (2010) Climate change effects on fishes and fisheries: towards a cause-and-effect understanding. J Fish Biol 77:1745-1779

Pörtner HO, Bock C, Reipschläger A (2000) Modulation of the cost of pHi regulation during metabolic depression: a ${ }^{31} \mathrm{P}-\mathrm{NMR}$ study in invertebrate (Sipunculus nudus) isolated muscle. J Exp Biol 203:2417-2428

Pörtner HO, Mark FC, Bock C (2004) Oxygen limited thermal tolerance in fish? Answers by nuclear magnetic resonance techniques. Respir Physiol Neuro 141:243-260
Pörtner HO, Bock C, Knust R, Lannig G, Lucassen M, Mark FC, Sartoris FJ (2008) Cod and climate in a latitudinal cline: physiological analyses of climate effects in marine fishes. Clim Res $37: 253-270$

Pörtner HO, Schulte PM, Wood CM, Schiemer F (2010) Niche dimensions and limits in fishes: an integrative view. Illustrating the role of physiology in understanding ecological realities. Physiol Biochem Zool 83:808-826

Pörtner HO, Karl DM, Boyd PW, Cheung WL, Lluch-Cota SE, Nojiri Y, Schmidt DN, Zavialov PO (2014) Ocean systems. In: Climate Change 2014: Impacts, Adaptation, and Vulnerability. Part A: Global and Sectoral Aspects. Contribution of Working Group II to the Fifth Assessment Report of the Intergovernmental Panel on Climate Change. In: Field CB, Barros VR, Dokken DJ, Mach KJ, Mastrandrea MD, Bilir TE, Chatterjee M, Ebi KL, Estrada YO, Genova RC, Girma B, Kissel ES, Levy AN, MacCracken S, Mastrandrea PR, White LL (eds). Cambridge University Press, Cambridge, United Kingdom and New York, NY, USA

Righton DA, Andersen KH, Neat F, Thorsteinsson V, Steingrund P, Svedäng H, Michalsen K, Hinrichsen HH, Bendall V, Neuenfeldt S, Wright P, Jonsson P, Huse G, van der Kooij J, Mosegaard H, Hüssy K, Metcalfe J (2010) Thermal niche of Atlantic cod Gadus morhua: limits, tolerance and optima. Mar Ecol Prog Ser 420:1-13

Rimoldi S, Terova G, Brambilla F, Bernardini G, Gornati R, Saroglia M (2009) Molecular characterization and expression analysis of $\mathrm{Na}^{+} / \mathrm{H}^{+}$exchanger (NHE)-1 and c-Fos genes in sea bass (Dicentrarchus labrax, L) exposed to acute and chronic hypercapnia. J Exp Biol Ecol 375:32-40

Sarazin G, Michard G, Prevot F (1999) A rapid and accurate spectroscopic method for alkalinity measurements in sea water samples. Water Res 33:290-294

Schurmann H, Steffensen JF (1997) Effects of temperature, hypoxia and activity on the metabolism of juvenile Atlantic cod. J Fish Biol 50(6):1166-1180

Seidelin M, Brauner CJ, Jensen FB, Madsen SS (2001) Vacuolartype $\mathrm{H}^{+}$-ATPase and $\mathrm{Na}^{+}, \mathrm{K}^{+}$-ATPase expression in gills of Atlantic salmon (Salmo salar) during isolated and combined exposure to hyperoxia and hypercapnia in fresh water. Zool Sci 18:1199-1205

Soofiani NM, Hawkins AD (1982) Energetic costs at different levels of feeding juvenile cod, Gadus morhua L. J Fish Biol 21(5):577-592

Taboada FG, Anadón R (2012) Patterns of change in sea surface temperature in the North Atlantic during the last three decades: beyond mean trends. Clima Chang 115:419-431

Takahashi T, Olafsson J, Goddard JG, Chipman DW, Sutherland SC (1993) Seasonal variation of $\mathrm{CO}_{2}$ and nutrients in the high-latitude surface oceans: a comparative study. Glob Biogeochem Cyc 7(4):843-878

Tresguerres M, Katoh F, Jasinska Fenton H, Goss GG (2005) Regulation of branchial $\mathrm{V}-\mathrm{H}^{+}$-ATPase, $\mathrm{Na}^{+} / \mathrm{K}^{+}$-ATPase and NHE2 in response to acid and base infusions in the Pacific spiny dogfish (Squalus acanthias). J Exp Biol 208:345-354

Wahlquivst I, Nilsson S (1977) The role of sympathetic fibres and circulating catecholamines in controlling the blood pressure and heart rate in the cod, Gadus morhua. Comp Biochem Physiol 57C:65-67

Wilson RW, Wilson JM, Grosell M (2002) Intestinal bicarbonate secretion by marine teleost fish - why and how? BBA Biomem 1566(1-2):182-193

Wittmann AC, Pörtner HO (2013) Sensitivities of animal taxa to ocean acidification. Nature Clim Chang: doi:10.1038/NCLIMATE1982

Wu SC, Horng JL, Liu ST, Hwang PP, Wen ZH, Lin CS, Lin LY (2010) Ammonium-dependent sodium uptake in mitochondriumrich cells of medaka (Oryzias latipes) larvae. Am J Physiol Cell Physiol 289(2):237-250 